\title{
Sensitisation of Nociceptors - What are Ion Channels Doing?
}

\author{
Michael J.M. Fischer*, Stephanie W.Y. Mak and Peter A. McNaughton
}

Department of Pharmacology, University of Cambridge, UK

\begin{abstract}
Nociceptors are peripheral sensory neurones which respond to painful (noxious) stimuli. The terminals of nociceptors, which have a high threshold to stimulation in their native state, undergo a process known as sensitisation, or lowering of threshold, following injury or inflammation. Amongst sensory receptors, sensitisation is a property unique to nociceptors. A shift in the stimulus-response function of nociceptors renders them more sensitive, resulting in both a reduction in the activation threshold, such that previously non-noxious stimuli are perceived as noxious (allodynia) and an increased response to suprathreshold stimuli (hyperalgesia). Sensitisation protects us from harm and is essential for survival, but it can be disabling in conditions of chronic inflammation. This review focuses on three stages in sensitisation: 1) Inflammatory mediators, which are released from damaged resident cells and from others that invade in response to inflammation, and include bradykinin, prostaglandins, serotonin, low $\mathrm{pH}$, ATP, neurotrophins, nitric oxide and cytokines; 2) Intracellular signalling molecules which are important in transmitting the actions of inflammatory mediators and include protein kinase A and C, Src kinase, mitogen-activated protein kinases and the membrane lipid PIP 2 ; and 3) Ion channel targets of intracellular signalling which ultimately cause sensitisation and include the temperaturesensitive transient receptor potential channels, acid-sensitive ion channels, purinoceptor-gated channels, and the voltagesensitive sodium, potassium, calcium and HCN channels.
\end{abstract}

Keywords: Pain, hyperalgesia, inflammation, cell signalling.

\section{INTRODUCTION}

Sensory neurones transduce mechanical, thermal and chemical stimuli into nerve impulses which then travel to higher centres to initiate painful sensations, a process referred to as nociception [1]. The activation of specific receptors or ion channels underlies the transduction of noxious stimuli into action potentials at peripheral nociceptive nerve terminals. Action potentials are then relayed via the dorsal horn of the spinal cord to the primary somatosensory area of the cerebral cortex, where the sensation of pain is experienced. Although there is a positive correlation between stimulus intensity and reported pain intensity, a large degree of plasticity is found at all levels of the nociceptive system which means that the experience of pain is highly variable [2]. Following inflammation or damage, noxious stimuli can evoke an exaggerated and prolonged pain (hyperalgesia) and pain thresholds can be lowered so that stimuli that are normally innocuous now become noxious (allodynia). Previously 'silent' nociceptors can become responsive to thermal or mechanical stimuli when sensitised by inflammatory substances or tissue injury $[3,4]$. Most of these mechanisms have a rapid onset and are readily reversible. Longer term changes are found during chronic inflammation and in neuropathic pain, a disabling condition in which partial damage to peripheral nerves causes long-lasting allodynia and hyperalgesia. These longterm changes in gene expression will be discussed in the context of the relevant receptors.

*Address correspondence to this author at the Department of Pharmacology, University of Cambridge, Tennis Court Road, Cambridge CB2 1PD, UK; Fax: +44 1223 334100: E-mail: mjmf2@cam.ac.uk
During the process of inflammation, a mixture of inflammatory mediators such as peptides (bradykinin), lipids (prostaglandins), neurotransmitters (ATP), protons and neurotrophins (NGF) is released. Some of these mediators directly excite nociceptors, inducing painful sensations, while others sensitise nociceptors. The release of neuropeptides from peripheral neurones supports plasma extravasation of further mediators and chemoattraction of inflammatory cells, a process termed "neurogenic inflammation". The sensitisation of the primary afferent neurones by local inflammatory mediators can occur by a direct action on the sensory neurones, or it can involve an indirect action on non-neuronal cells, especially but not exclusively on immune cells, from which further inflammatory mediators can then be released.

In this review, peripheral sensitisation is considered to be an increase in the responsiveness of primary afferent nociceptors compared to baseline. Repetitive stimulation, a part of the definition of sensitisation in a behavioural setting, is not required to elicit sensitisation at a molecular level. Sensitisation can arise for a variety of reasons, which can be broadly separated into effects on ion currents directly activated by the noxious stimulus (generator currents) and effects on ion channels involved downstream in the initiation of action potentials. Sensitisation is distinct from the actual process of initiating action potentials, though some of the ion channels responsible for determining the action potential threshold (e.g. hyperpolarisation-activated cyclic nucleotide gated channels, $\mathrm{HCN}$ ) and for causing excitation (e.g. sodium channels) are also targets for sensitisation (see below). 
Visceral nociceptors are not as well studied as somatic, especially cutaneous, afferents. Many results concerning mediators and receptors have, however, been replicated in visceral pain models including all the mediators and receptors mentioned below [5]. A few differences have been reported, e.g. the IB4-positive population is smaller in visceral compared to somatic afferents, almost all visceral afferents are peptidergic and TRPV1-positive neurones are more prevalent than in somatic nociceptors $[6,7]$.

The mediators of inflammatory pain are better established than the processes involved in neuropathic pain, for this reason this review will focus on inflammatory pain. In the case of neuropathic pain some similar mechanisms of sensitisation and gene regulation have recently been reviewed [8]. The first part of the review focuses on extracellular mediators released by inflammation and leading to sensitisation. In the second part of this review we discuss how these mediators activate a rather small number of intracellular signalling pathways and mediators in order to induce peripheral sensitisation. The main mechanisms characterised to date are (i) phosphorylation of ion channels already in the surface membrane, and (ii) altered cell surface expression of ion channels, which can be modulated both in the short term by trafficking of ion channels from an intracellular store and in the longer term by altered gene expression. The third part of the review discusses the impact the activation of intracellular signalling pathways has on the most important ion channels engaged in sensitisation.

\section{INFLAMMATORY MEDIATORS OF SENSITISA- TION}

There are many extracellular mediators which contribute to nociceptor sensitisation. The importance of any specific factor has been proven difficult to dissect, since many of these release others, generating a multi-focussed web of factors. Ryan and Majno noted that inflammation is most likely mediated by vascular leakage, due to the actions of the kinins, vasoactive amines (histamine, serotonin) and the prostaglandins [9]. Many more groups of compounds might be involved, based on measurements from human inflamed tissue and pharmacological studies [10]. The multifactorial nature of inflammation led to the idea of an 'inflammatory soup' or 'inflammatory mediators' [11]. Unfortunately, this term is used for different compositions and concentrations, usually involving bradykinin, prostaglandin $\mathrm{E}_{2}$, histamine and serotonin, often at a lowered $\mathrm{pH}$. The composition is clearly artificial and omits some important mediators found subsequently.

\section{Bradykinin}

Bradykinin is amongst the most potent sensitizing agents. Injection of bradykinin into human skin produces a dosedependent pain and heat hyperalgesia, suggesting that bradykinin is capable of exciting and sensitising nociceptors to heat [12]. Bradykinin is formed by cleavage of low molecular weight tissue kininogen by the protease kallikrein to liberate lys-bradykinin (kallidin) which is then cleaved further to bradykinin by an aminopeptidase [13]. Kallikreins are serine proteases activated from prekallikrein by activated FactorXII of the coagulation cascade [14]. Bradykinin and kallidin are both potent $\mathrm{B}_{2}$ receptor activators, and are responsible for acute sensitisation and activation [15].
Functional $\mathrm{B}_{2}$ receptors are widely expressed, both in the nervous system and in non-neuronal tissues [16]. Kallikrein has also been shown to activate the $\mathrm{B}_{2}$ receptor directly [17]. Further cleavage of the $\mathrm{C}$-terminal arginine of bradykinin liberates des-arg ${ }^{9}$ bradykinin, which has little action at the $\mathrm{B}_{2}$ receptor but is a potent activator of the $B_{1}$ receptor. The $B_{1}$ receptor is absent or expressed at low levels under normal conditions, but during prolonged inflammation $\mathrm{B}_{1}$ receptors are induced in primary nociceptors by glial cell derived neurotrophic factor and can sensitise the heat evoked current in dorsal root ganglia (DRG) neurones [18, 19]. Both bradykinin receptors are G-protein coupled and activate $\mathrm{G}_{\mathrm{q}} /$ phospholipase $\mathrm{C}_{\beta}\left(\mathrm{PLC}_{\beta}\right)$ and $\mathrm{G}_{\mathrm{i}} /$ phospholipase $\mathrm{A}_{2}[20]$. Downstream of phospholipase $\mathrm{C}_{\beta}$ are the mediators $\mathrm{IP}_{3} /$ diacylglycerol and protein kinase $\mathrm{C}(\mathrm{PKC})$, as discussed below. Downstream of phospholipase $\mathrm{A}_{2}$, arachidonic acid from the cell membrane is converted to leukotrienes, hydroperoxyeicosatetraenoic acids (HPETEs), epoxyeicosatrienoic acids (EETs) and, most importantly, prostaglandins which lead to activation of protein kinase A (PKA). Bradykinin is also a good example of an inflammatory mediator which causes the secondary release of transmitters from neurones, including calcitonin generelated peptide, substance $\mathrm{P}$ and acetylcholine [21], and also the release of further inflammatory mediators from immune cells, including NGF, interleukins, tumour necrosis factor, prostaglandins and leukotrienes [22, 23]. Bradykinin decreases the threshold of thermally-activated ion channels such as TRPV1, and it also sensitises nociceptors by modulating other ion channels, for example by reducing the activity of potassium channels, which makes cells more excitable by decreasing the resting potential.

\section{Prostaglandins}

Prostaglandins (PG) are derived from arachidonic acid, which is released from membrane phospholipids by the esterase action of phospholipase $\mathrm{A}_{2}$. $\mathrm{PGE}_{2}$ and $\mathrm{PGI}_{2}$ have been found to be more potent sensitisers than $\mathrm{PGF}_{2 \mathrm{a}}, \mathrm{PGD}_{2}$ or $\mathrm{TxA}_{2}$ in humans [24] and in animal models [25]. Both have similar effects but different time courses of action [26]. The actions of $\mathrm{PGE}_{2}$ and $\mathrm{PGI}_{2}$ are transduced by the Gprotein coupled EP and IP receptors, respectively [27, 28], and in both cases the main action in primary sensory neurones is to couple to $G_{s}$, which in turn activates adenylate cyclase to release cyclic adenosine monophosphate (cAMP) and thus activate PKA, as discussed below [29]. Production of prostaglandins via cyclooxygenases 1 and 2 is the target of the most common used painkiller family. Cyclooxygenase inhibition reduced the activation of sensory neurones [30]. Prostaglandins sensitise sodium and calcium channels and suppress outward potassium currents [31]. An alternative cAMP-dependent pathway mediated via PKC $\varepsilon$ has been described in IB4-positive neurones [32]; the observed sensitisation in inflamed tissue is conveyed by Epac1 (the exchange protein directly activated by cAMP) from cAMP to PKCE [33]. Given the convergence of so many pathways on $\mathrm{G}_{\mathrm{s}}$ proteins, it is not surprising that opioids, which have been shown to be potent peripheral analgesics in addition to their central actions, owe their peripheral actions to a counterbalancing activation of $\mathrm{G}_{\mathrm{i}}$, which inhibits adenylate cyclase [34]. Arachidonic acid is not only a substrate for production of prostaglandins but is also processed by 
lipoxygenases and cytochrome p450 epoxygenase. Injection of the leukotrienes lowered nociceptive thresholds [35] and inhibition of 5- and 12-lipoxygenase reduced development of hyperalgesia [36]. There is also some indication of modulation of pain by EETs [37].

\section{Histamine}

The main source of histamine is mast cells, the degranulation of which is stimulated by substance $P$ and vasoactive intestinal peptide [38, 39]. Extracellular levels of histamine are substantially increased in inflammation, but its contribution to sensitisation is unclear, since histamine evokes the sensation of itch rather than pain and directly activates only a minimal fraction of neurones [40].

\section{Serotonin}

Serotonin, or 5-hydroxytryptamine (5-HT), is present at increased levels in inflamed tissues, and is released mainly from mast cells and platelets [41]. Serotonin can directly excite neurones via activation of the $5-\mathrm{HT}_{3}$ receptor, which is an ion channel, and can in addition sensitise via the $\mathrm{G}_{\mathrm{q}^{-}}$ coupled $5-\mathrm{HT}_{2 \mathrm{~A}}$ receptors found in neurones [42, 43]. Inflammatory pain was shown to be reversed by an antagonist for $5-\mathrm{HT}_{2 \mathrm{~A}}$ [44]. In trigeminal pain $5-\mathrm{HT}_{1}$ receptor subtypes are involved, and antagonists can be used to treat migraine [45]. At a molecular level, sensitisation by 5-HT has been demonstrated for sodium channels [46]. Indirectly, serotonin sensitises by activating monocytes [47] and by interleukin 6 release from endothelial cells [48].

\section{Protons}

Acidic conditions occur in inflammation and ischemia. Protons can directly activate transducer channels, as discussed below, but the necessary $\mathrm{pH}$ levels are rarely found even in infections or severe tissue damage [49, 50]. Only intradermal infusion of $\mathrm{pH} 5$ and below induces pain in humans, although owing to the high tissue buffering capacity the actual tissue $\mathrm{pH}$ attained may be less acidic than this and the corresponding $\mathrm{pH}$ at the nerve terminals remains unknown [51]. Furthermore, these extreme proton concentrations reduced conduction of many channels [52] and can lead to conduction block [53]. There might however be exceptions such as stomach afferents which are continuously exposed to extreme proton concentrations in the vicinity of lesions [54]. Protons also commonly act as subthreshold sensitising agents, acting cooperatively with bradykinin, ATP and inflammatory mediators [55-58].

\section{ATP}

ATP activates both the ionotropic P2X purinoceptors and the metabotropic P2Y receptors. High levels of ATP are required for purinoceptor activation, and are seldom attained by tissue damage or ischemia, but can be achieved by release from (sympathetic) neurones [59]. We discuss the P2Y receptors in this section and the $\mathrm{P} 2 \mathrm{X}$ receptors in the final section on ion channels. DRG neurones express P2Y1 and $\mathrm{P} 2 \mathrm{Y} 2$ receptors [60]. P2Y1 activation in DRG neurones inhibits $\mathrm{Ca}_{\mathrm{V}} 2.2$ and $\mathrm{P} 2 \mathrm{X} 3$ channels [61]. Activation of $\mathrm{PKC \varepsilon}$ following P2Y1 receptor activation sensitises TRPV1 [62]. P2Y2 receptor activation also sensitises TRPV1 in expression systems and leads to TRPV1-mediated thermal hyperalgesia [63]. Following tissue injury, activation of extracellular signal-regulated kinases (ERKs) is mediated by $\mathrm{P} 2 \mathrm{Y}$ receptors [64] and gene regulation is triggered via the cAMP response element binding protein CREB [65]. In contrast to these actions mediated by ATP and the P2 family of receptors, activation of the $\mathrm{P} 1$ receptors by adenosine decreases cellular excitability and nociception, and adenosine has analgesic actions in behavioural experiments [66].

\section{Neurotrophins}

Neurotrophins, including nerve growth factor (NGF), brain-derived neurotrophic factor (BDNF) and neurotrophin $3-5$, activate the tyrosine kinase-couples receptors of the Trk family. Neurotrophin effects can be separated into short-term effects mediated by phosphorylation and trafficking of ion channels to the membrane, and long-term changes mainly caused by changes in gene expression $[67,68]$. Injection of NGF has a rapid hyperalgesic effect, and also causes a hyperalgesia lasting for many days [69]. The short term action of NGF in promoting hyperalgesia is thought to be predominantly mediated via TrkA receptors [70]. NGF acutely sensitised the activation of sensory neurones by capsaicin, an effect mediated by TRPV1 [71]. NGF binds to TrkA, causing phosphorylation of tyrosine Y760 and thus activating the PI3K-Src signalling pathway to phosphorylate Y200 of TRPV1, which causes enhanced insertion of TRPV1 into the cell membrane [72, 73]. There have also been reports that NGF alters the activation threshold of TRPV1 via p42/44 mitogen-activated protein kinases (MAPK) [74]. NGF is an important link to stimulation of the immune system, including mast cell degranulation, cytokine production and $\mathrm{B}-$ and $\mathrm{T}$-cell proliferation $[75,76]$. The importance of NGF as an inflammatory mediator is also due to retrograde transport to the cell nucleus, where it induces a long term upregulation of gene expression, including TRPV1, acid-sensing ion channels (ASIC) and sodium channels, neuropeptides such as substance $\mathrm{P}$ and calcitonin gene-related peptide (CGRP), and bradykinin receptors [7780].

\section{Nitric Oxide}

Nitric oxide (NO) is produced by the nitric oxide synthases, of which there are three isoforms, endothelial neuronal and inducible (eNOS, nNOS and iNOS, respectively). NO producing enzymes can be activated by noxious irritants, by NO itself, or in DRG neurones following nerve injury [81-83]. Local inhibition of NO synthesis reduces inflammatory hyperalgesia [84]. Nitric oxide is a short-lived inflammatory mediator and therefore has only very local effects, but it can pass readily through cell membranes and therefore often has effects in cells adjacent to those in which the NO is produced. The most well-known downstream pathway is the direct activation of soluble guanylate cyclase by NO, leading to enhanced levels of cGMP and consequent activation of protein kinase $\mathrm{G}$ in target cells. Bradykinin can also stimulate the formation of cGMP in nociceptive neurones [85], and while for central sensitisation cGMP seems to be important [86], in primary afferents the relevance of cGMP seems minor in comparison to cAMP $[87,88]$. NO can also act directly on membrane proteins to S-nitrosylate cysteine residues, leading to the breaking of Cys-Cys bonds and a consequent change in 
protein structure [89]. An important additional long-term effect of NO is the upregulation of cyclooxygenase 2 [90].

\section{Cytokines}

Immune cells contribute to sensitisation via a complex network [91]. TNF $\alpha$ is released from monocytes and tissue macrophages by several stimuli including microbial products, complement and tissue damage, and induces sensitisation with both rapid and long-lasting components [92]. TNF $\alpha$ activates the TNFR1 and TNFR2 receptors, which are upregulated during inflammation [93]. The importance of TNF $\alpha$ in chronic inflammation such as arthritis is illustrated by the success of monoclonal antibodies against it [94]. TNF $\alpha$ is the trigger for the release of a whole cascade of cytokines, including NGF and the interleukins $1 \beta, 6$ and 8 , which are amongst the strongest proinflammatory cytokines [95]. Among these interleukin $1 \beta$ and NGF are especially potent in inducing lasting sensitisation [96]. These cascades also finally lead to prostaglandin formation. A link to the p38 MAPK pathway has been demonstrated [97]. In addition to this indirect action through a downstream cascade, there is also evidence for a direct action of cytokines on nociceptors [98, 99]. Members of the CCL family also trigger hyperalgesia, and an effect in sensitizing TRPV1 has been shown for CCL2 and CCL3 [100, 101]. Many other chemokines have been described [102].

\section{Prokineticins}

Two human proteins named prokineticin 1 and 2 and their corresponding G-protein-coupled receptors have been identified [103]. Systemic injection of a prokineticin receptor agonist induces a biphasic hyperalgesia [104], and the heat and capsaicin sensitivity of prokineticin receptor 1 knockout mice is lower than in wildtype, implying a tonic sensitizing effect on TRPV1 in vivo [105]. Prokineticin receptors are expressed in neurones and their activation sensitised TRPV1, suggesting a role for prokineticins in physiological inflammation and hyperalgesia [106].

\section{Proteases}

Proteases are released during injury and blood clotting, and act upon protease-activated receptors (PARs), a family of four $\mathrm{G}$ protein-coupled receptors, to regulate hemostasis, inflammation, pain, and repair. PARs are cleaved by proteases at a specific site near the extracellular N-terminus, unmasking a tethered ligand which is then able to bind to and activate the receptor. PAR2 seems responsible for sensitisation, it is localised in most nociceptive neurones, and PAR2 in particular seems to be important in sensitising neurones via PKC-dependent phosphorylation of TRPV1 [107].

\section{INTRACELLULAR SIGNALLING MECHANISMS}

The previous section has dealt with a plethora of mediators released during inflammation. The number of intracellular signalling pathways activated by these mediators is, by contrast, much less. Phosphorylation of target membrane ion channels is a key driver of sensitisation; the key players here seem to be the serine/threonine protein kinases PKA and PKC, and the tyrosine kinases Src and MAPK, though important roles for other kinases no doubt remain to be discovered. Principal phosphatases currently known to drive dephosphorylation include the calciumdependent phosphatase calcineurin (PPP3, formerly PP2B) and the SHP tyrosine phosphatases [108]. Dephosphorylation normally follows activation and is often driven by increased intracellular calcium levels $[109,110]$. A change in phosphorylation state can be accompanied with trafficking to or from the plasma membrane $[73,111,112]$.

\section{Protein Kinase A}

PKA is activated by pathways which activate adenylate cyclase, leading to the production of cAMP. Stable analogs of cAMP cause sensitisation in behavioural models [113] and in in vitro models using rat nociceptive afferent neurones $[88,114]$. PKA catalytic subunits were shown to translocate to the plasma membrane when activated [115]. Phosphorylation by PKA sensitises TRP channels, and sodium, calcium and potassium channels (Table 1).

\section{Protein Kinase $\mathbf{C}$}

Activation of PKC can sensitise as well as activate nociceptors [116]. PKC has several calcium-dependent and independent isoforms with different contributions to sensitisation [117]. Of particular importance is PKCE, which sensitises heat-evoked activation of DRG neurones [118]. Subtype-specific antagonists and $\mathrm{PKC \varepsilon}$ deficient mice support that this isoform is vital for acute inflammation [119]. One report found that PKC $\alpha$ was also involved in sensitisation of TRPV1 [120]. Systemic inhibition of PKC $\beta$ reduced diabetic hyperalgesia through reduction of cGMP in DRG neurones [121]. PKC activation sensitises capsaicinstimulated neuropeptide release [122]. It was demonstrated that PKC activation can reduce the temperature threshold of TRPV1, even to below body temperature, thus leading to tonic activation of pain-sensitive afferents $[58,123]$. PKC is also involved in sensitisation in neuropathic pain models, including alcoholic, diabetic and chemotherapy-induced neuropathy [124-126].

Members of the A-kinase anchoring protein (AKAP) family associate both PKA and PKC with their targets [127]. It has recently been shown that the AKAP79 isoform binds to both TRPV1 and TRPV4 and in this way maintains PKA, PKC and the phosphatase calcineurin in close proximity with their target serines and threonines. Downregulation or inhibition of binding of AKAP79 completely disrupts sensitisation via both PKA and PKC [128, 129]. These observations suggest that the binding of AKAP79 to TRPV1 may be a "master switch" whose inhibition could be used to antagonise sensitisation via both the PKA and the PKC pathways.

\section{Src Kinase}

The tyrosine kinase Src has recently been shown to play a key role in sensitisation of TRPV1. Binding of NGF to the TrkA receptor initiates several signalling cascades, amongst them the ras-MAPK pathway (see next section) and the PI3K-PKB-Src pathway. Src phosphorylates an N-terminal tyrosine in TRPV1, leading to a rapid increase in trafficking to the neuronal cell membrane and therefore to an enhanced response to activators of TRPV1 [73]. This pathway seems likely to explain the rapid increase (minutes) in membrane TRPV1 following exposure to NGF, while increased 
Table 1. Summary of the regulation of the ion channels and intracellular pathways discussed in this review. $\uparrow$ denotes an activation or sensitisation, $\downarrow$ an inhibition or desensitisation, $\leftrightarrow$ evidence that there is no regulation. $\varnothing$ indicates that we have found no report of modulation. In the case of conflicting evidence a combination of symbols is given. For calcium and potassium channels the affected channel subtypes are mentioned when known, or marked as NI (not identified) if currents were measured without clear identification of subtypes

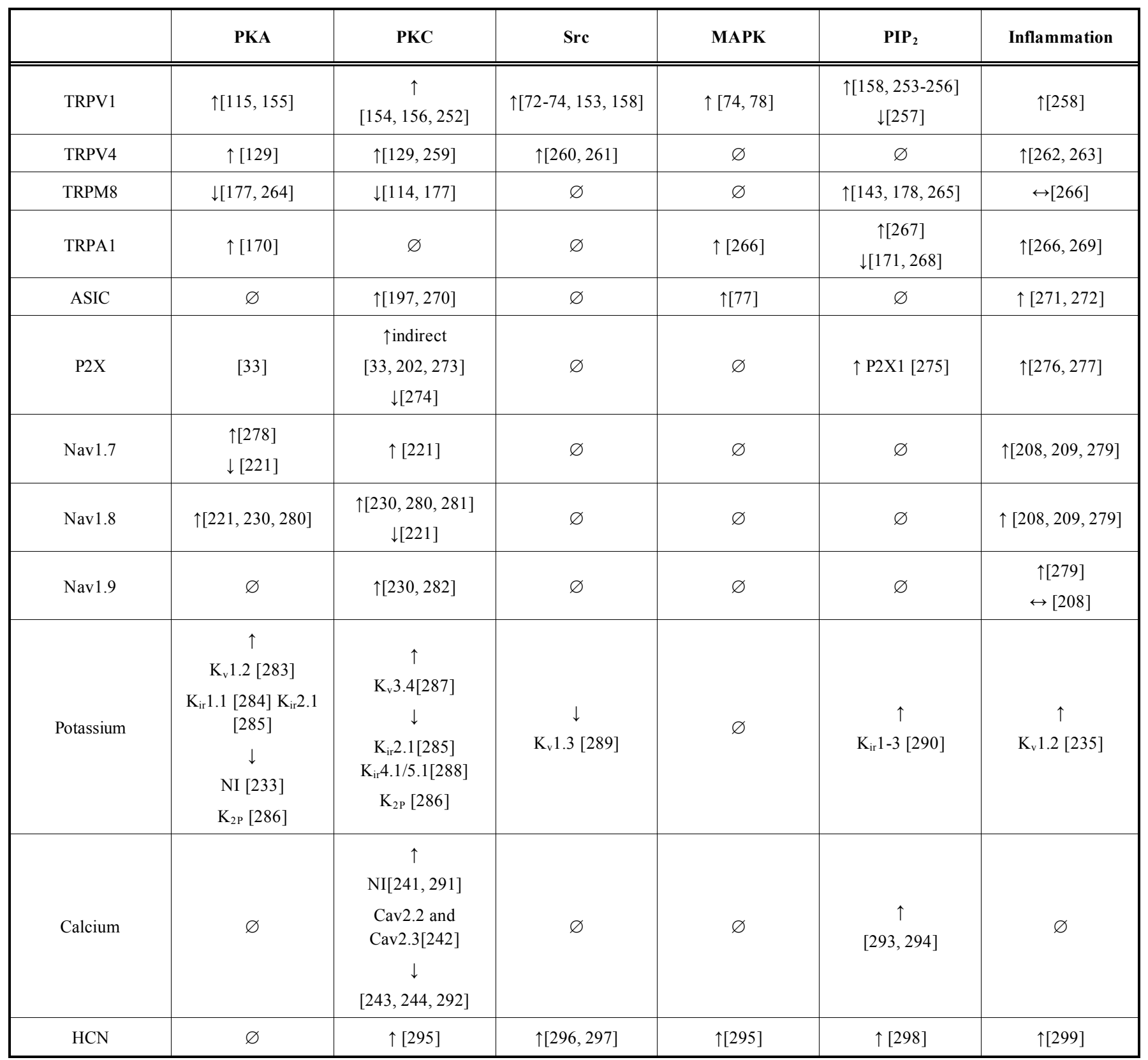

expression following activation of the ras-MAPK pathway is responsible for more long-term sensitisation (days).

\section{Mitogen-Activated Protein Kinases (MAPK)}

Kinases of the MAPK family (ERK, p38, and JNK) can contribute to nociceptor sensitisation, although their role in central pain processing is more prominent [130]. MAPK inhibitors alleviate hyperalgesia and allodynia in inflammatory pain models, though basal sensory threshold are little affected [131]. ERKs are activated in DRG neurones by NGF [132], by chemical and electrical stimulation [133] and by inflammation by Freund's adjuvant
[134]. Similarly, p38 MAPK in DRG neurones is also activated by NGF [135], by capsaicin and by thermal stimulation [136]. P38 and c-Jun are both activated in DRG neurones by inflammation $[137,138]$. Both p38 and c-Jun aminoterminal kinases are activated by TNF $\alpha$ [139], and cJun regulates expression of neuropeptides vasoactive intestinal peptide (VIP) and neuropeptide Y (NPY) in DRG neurones [140].

\section{PIP $_{2}$}

Phosphatidyl-inositol 4,5-bisphosphate $\left(\mathrm{PIP}_{2}\right)$ is an ubiquitous component in the plasma membrane. $\mathrm{PIP}_{2}$ levels 
in the plasma membrane have been found to regulate the activities of several neuronal transporters and receptors [141], including sodium-proton exchangers, inward rectifier potassium channels, epithelial sodium channels, ryanodinesensitive calcium channels, several TRP channels, P2X channels and HCN channels (see Table 1). Probably the most significant regulation in the context of nociception is the enhancement of activity of TRP channels caused by elevations of $\mathrm{PIP}_{2}$ [142], and the consequent loss of activity when $\mathrm{PIP}_{2}$ levels are depleted, for instance by an elevation of intracellular calcium [143]. See further discussion below.

\section{MODULATION OF ION CHANNELS}

The following section discusses ion channels thought to be of major importance for nociceptor sensitisation. Interestingly, many of them are rather selectively expressed in sensory neurones [144]. The IUPHAR nomenclature http://www.iuphar-db.org is used.

\section{TRP Channels}

Members of the transient receptor potential (TRP) family have received a great deal of attention in the context of pain processing [145]. The name originates from the transient receptor potential found in the visual receptors of Drosophila melagnogaster with the trp mutations. The defective gene was later identified as the canonical TRP receptor, an ion channel with a characteristic ankyrin repeat motif in the Nterminal cytoplasmic domain [146]. A large family of TRP channels has been identified [147]. This review focuses on the three thermally sensitive TRP channels TRPV1, TRPA1 and TRPM8, which are expressed in somatosensory neurones [148] and are thought to be the main TRP ion channels involved in sensitisation.

TRPVI is the founder member of the vanilloid group [149], and is activated by an wide variety of physical (heat $>42^{\circ} \mathrm{C}$, membrane stretch) and chemical stimuli [150]. Chemical activators are structurally diverse and include vanilloids such as capsaicin and resiniferatoxin, low $\mathrm{pH}$, endogenous lipids and ethanol. The sensory role of TRPV1 in intact animals is still not completely clear, because although it is clearly heat-activated and activation causes a burning sensation, deletion of TRPV1 has rather little effect on thermal thresholds in vivo $[151,152]$. A pivotal role for TRPV1 in inflammatory heat hyperalgesia is, however, supported by a large body of evidence using TPRV1deficient mice [151, 152]. Phosphorylation of TRPV1 by PKA, PKC and src leads to sensitisation to a wide range of activating stimuli, including heat, capsaicin, low $\mathrm{pH}$ and the endogenous cannabinoid anandamide [118, 153, 154]. The respective phosphorylation sites for PKA and PKC have been identified $[155,156]$. A previous proposal that sensitisation of TRPV1 could be explained by removal of $\mathrm{PIP}_{2}$ following activation of phospholipase $\mathrm{C}$ by inflammatory mediators such as bradykinin or NGF [157] is now not thought to be correct because application of PIP $_{2}$ to inside out patches was found to enhance rather than reduce the activity of TRPV1 channels [158]. In addition to sensitisation of channels already located in the cell membrane, new TRPV1 channels can also be rapidly trafficked to the cell membrane via exocytosis from an intracellular store, following activation of the PI3K-Src cascade by mediators such as NGF and insulin [73, 112,
159]. Long-term upregulation of expression of TRPV1, driven by growth factors such as NGF, and downstream by the ras-MAPK signalling pathway, are also likely to play a role in long-term thermal hyperalgesia $[78,160]$. Evidence has been accumulating for the involvement of TRPV1 in a wide range of diseases, particularly in gastrointestinal, respiratory and bladder diseases [161]. Sensitisation of TRPV1 to a threshold below body temperature could explain ongoing nociceptive input and therefore pain in inflammatory conditions such as arthritis. TRPV1 has sufficient calcium conductance on its own to trigger calciumdependent mechanism like neuropeptide release without the contribution of voltage-gate calcium channels [162].

TRPA1 detects chemical irritants such as acrolein, a constituent of smoke, and agonists such as allyl isothiocyanate (mustard oil), allicin or formalin, all of which induce a burning or pricking sensation [163, 164]. Unsaturated electrophilic structures are a common motif and a corresponding covalent and irreversible activation mechanism, targeting intracellular N-terminal cysteine residues, has been described $[165,166]$. The expression of TRPA1 is regulated by NGF [163]. Animals deficient in TRPA1 were less sensitive in several pain models [167]. A unique feature of TRPA1 is its direct gating by intracellular calcium, rendering TRPA1 a potential amplifier of other stimuli which reach the necessary calcium threshold [168, 169]. Sensitisation of TRPA1 by bradykinin appears to involve both PLC and PKA pathways in sensory neurones [170]. The protease-activated receptor 2 sensitises TRPA1 via reduction of membrane $\mathrm{PIP}_{2}$ levels [171]. The sensitivity of TRPA1 to cold has been debated [164, 168], but recent evidence supports a slow activation at low temperatures, which may have been missed by some temperature protocols $[163,172]$. Both TRPV1 and TRPA1 are sensors of chemical irritants, and some algogens activate both. Such agonists still activate nociceptive neurones when either channel is individually deleted, but in double knockout animals the activation completely vanishes $[173,174]$.

TRPM8 was cloned by two groups $[175,176]$. It is activated physically by cooling and by a variety of chemicals e.g. menthol. Recent behavioural studies show that activation of TRPM8 antagonises capsaicin-induced nociception [114]. TRPM8 is co-expressed with bradykinin and prostaglandin receptors, and application of the respective mediators reduced the TRPM8 response to cooling and lowered the threshold temperature via pathways thought to involve PKC and PKA [177]. PKC-dependent dephosphorylation of TRPM8 via protein phosphatase 1 (PP1) has also been proposed to inhibit TRPM8 [114]. PIP ${ }_{2}$ cleavage desensitises and $\mathrm{PIP}_{2}$ addition recovers TRPM8 activation, with the Cterminal TRP box appearing to be the critical $\mathrm{PIP}_{2}$ interaction site [178]. Mice deficient in TRPM8 have an impaired thermoception at least at near-ambient cool temperatures $[179,180]$, suggesting a role for TRPM8 in mediating innocuous cold perception. TRPM8 might also play a role in the nocifensive response to noxious cold [179]. In inflammation the temperature threshold of TRPM8 may be elevated and thus could explain cold pain at normally innocuous temperature [181]. The clinical role of TRPM8 is largely unknown. TRPM8 regulation has been reported in urogenital syndromes [182], suggesting a role for TRPM8 in these pathological states. 


\section{Other TRPs and Heteromers}

In addition to TRPV1, TRPA1 and TRPM8, other TRPs appear to work in concert to induce sensitisation in pathological states. TRPV2 and TRPV3 both sensitise on repeated activation in the absence of intracellular calcium $[183,184]$, and can be sensitised, as is TRPV1, by 2aminoethoxydiphenyl borate $[183,185,186]$. TRPV4 can be sensitised by activation of PKC [129, 187], by low $\mathrm{pH}[188]$ and by nitric oxide [189]. Intracellular calcium levels trigger the calcineurin-dependent desensitisation of many TRP channels [109, 190]. Recently, TRPC channels were found to contribute to intracellular calcium homeostasis [191].

TRP channels are tetramers. Due to their similarity, the possibility of heteromer formation has been investigated [192]. In many neurones TRP channels are coexpressed, and heteromers could give rise to channels with novel properties, as demonstrated for TRPC channels [193]. Several TRP channels with currently unclear function but strong changes in post-injury expression could alter neuronal sensitivity by such a mechanism [194].

\section{ASIC Channels}

Members of the ASIC family are activated by protons [195]. Local acidosis is observed during ischemia and inflammation and it is therefore tempting to attribute the pain caused by inflammation to activation of ASICs. Sensitivity to protons is not exclusive to members of this family. In skin, a lower $\mathrm{pH}$ sensitises all unmyelinated nociceptors to mechanical stimuli, whereas low-threshold mechanosensors are unaffected [51]. Proton-induced currents in DRG neurones are sensitised by nitric oxide, and the sensitisation was shown to depend on S-nitrosylation of ASICs at an external location rather than activation of soluble guanylate cyclase [196]. ASIC channels have been shown to be sensitised by PKC [197].

\section{P2X Purinoceptors}

Both P2X ion channels and P2Y G-protein coupled receptors (see discussion above) can modulate neuronal excitability [198]. In this section we discuss only the former. Application of ATP to human blisters caused pain [199]. $\mathrm{P} 2 \mathrm{X}$ receptor isoforms 1-3 are expressed in sensory neurones and in the heart in humans [200]. Peripheral inflammation enhances both the potency and effectiveness of locally administered P2X receptor agonists [201]. Although all $\mathrm{P} 2 \mathrm{X}$ receptors have a consensus sequence for $\mathrm{PKC}$ phosphorylation, several studies argue against a direct phosphorylation by PKC [202]. C-terminal Src inhibitory kinase inhibits $\mathrm{P} 2 \mathrm{X} 3$ receptor by $\mathrm{Y} 393$ phosphorylation [203]. An indirect sensitisation via interleukin $1 \beta$ is also caused by the $\mathrm{P} 2 \mathrm{X} 7$ receptor, which is expressed in immune cells [204], which may be the basis of the reduced painrelated behaviour and allodynia seen in P2X7 knockout animals [205].

\section{Sodium Channels}

Nine sodium channels are found in humans, but only those important in DRG neurones are discussed in this review. The properties of sodium channels differ in their activation threshold and their time constants for inactivation and for recovery from inactivation [206]. In native DRG neurones $\mathrm{Na}_{\mathrm{v}}$ subtypes 1.1 and 1.6 were found preferentially in A-fibre neurones, while 1.7, 1.8 and 1.9 were preferentially located in C-fibre populations [207]. Inflammation increases the expression of subtypes $1.3,1.7$ and 1.8 [208, 209]. Action potentials of nociceptors have a striking long duration and low maximum frequency [210].

Some sodium currents have been recognised for many years to be insensitive to tetrodotoxin (TTX), which provides a useful tool to distinguish the involvement of different isoforms [211, 212]. The TTX-resistant sodium currents are carried by $\mathrm{Na}_{\mathrm{v}} 1.8$ and $\mathrm{Na}_{\mathrm{v}} 1.9$, which are found only in a subpopulation of sensory neurones, and $\mathrm{Na}_{\mathrm{v}} 1.5$ which is only expressed in cardiac cells [213]. TTX-resistant sodium currents in nociceptive neurones are enhanced by inflammatory mediators [214]. The alpha subunits of sodium channels have several phosphorylation motifs for PKA and PKC [215]. In sensory neurones the peak sodium currents are increased and the current voltage-relationship was reported to shift to lower membrane voltages (i.e. in such a way as to enhance the ease of excitation of the neurone) following phosphorylation by PKA [46, 216].

$\mathrm{Na}_{V} 1.1$ channels are inhibited by PKA activation [217]. $\mathrm{Na}_{\mathrm{v}} 1.2$ expression in sensory neurones is so low that the relevance of these channels is unclear, and in addition the sodium currents are inhibited by PKA and PKC, which does not favour a role in hyperalgesia [207, 218]. $\mathrm{Na}_{\mathrm{v}} 1.7$ produces a fast activating and inactivating current [219]. Due to its slow inactivation from the closed state, $\mathrm{Na}_{\mathrm{v}} 1.7$ is more likely to be activated by slowly rising generator potentials than other sodium channels and is therefore well suited to mediate the slow firing activity in nociceptors [220]. $\mathrm{Na}_{\mathrm{v}} 1.7$ currents are attenuated by activation of PKA and PKC. PKA does not change the steady-state voltage dependence, while PKC shifts it in depolarizing direction [221]. $\mathrm{Na}_{\mathrm{v}}$ 1.7 DRG-specific knockouts showed reduced pain-related behaviour compared to wildtype mice [222]. $\mathrm{Na}_{\mathrm{v}} 1.8$ activates only upon strong depolarisation, as its threshold is some $20 \mathrm{mV}$ positive to the thresholds of other sodium currents [223]. $\mathrm{Na}_{\mathrm{v}} 1.8$ has been shown to be the major contributor to the upstroke of action potentials in nociceptors and to account for a large part of the current in trains of action potentials [224]. $\mathrm{Na}_{\mathrm{v}} 1.8$ currents are potentiated by activation of PKA [221, 225]. In contrast, PKC decreases $\mathrm{Na}_{\mathrm{v}} 1.8$ currents, and shifts the voltage dependence in a depolarizing direction [221]. Based on the phenotype of $\mathrm{Na}_{\mathrm{v}} 1.8$ knockout mice, the channel seems to be of minor importance for pain responses [226]. $\mathrm{Na}_{\mathrm{v}} 1.9$ is partially activated at the resting membrane potential, generating a small and persistent current; $\mathrm{PGE}_{2}$ reduces the time-constant of activation and shifts the currentvoltage relationship of activation and inactivation in a negative direction $[227,228] . \mathrm{Na}_{\mathrm{v}} 1.9$ knockout animals had normal mechanical and thermal thresholds, but had reduced inflammatory hyperalgesia and sensitisation by inflammatory mediators [229]. The sensitisation of $\mathrm{Na}_{\mathrm{v}} 1.9$ is mediated by PKC [230].

\section{Potassium Channels}

Potassium channels contribute to the background conductance in all neuronal cells. They are the largest family of ion-selective channels and can be categorized into four classes: voltage-gated, inwardly rectifying, tandem pore 
domain and calcium-activated potassium channels [231]. A reduction in potassium channel conductance increases neuronal excitability and the probability of repetitive discharge [232]. The conductance of potassium channels can be reduced by pathways stimulating cAMP formation and PKA-mediated phosphorylation in rat sensory neurones [233]. Potassium channels properties have been shown to be modulated by PKA, PKC, Src, $\mathrm{PIP}_{2}$ (see Table 1) and the protein tyrosine kinase PYK2 [234]. NGF and PKA can also regulate the expression and intracellular distribution of potassium channels [235, 236]. Inward rectifier potassium channels can be modified by the second messenger-sensitive minK potassium channel protein [237].

\section{Calcium Channels}

Modulation of calcium influx into the cytoplasm by voltage gated calcium channels or calcium permeable channels affects neuronal excitability and promotes exocytosis of neuropeptides such as substance P and CGRP from nociceptive neurones. Norepinephrine, gammaaminobutyric acid (GABA) and 5-HT have been demonstrated to inhibit calcium influx and to shift the voltage-dependence of calcium channels [238, 239]. The ten known calcium channel subtypes are not identically regulated. $\mathrm{Ca}_{\mathrm{v}} 2.2$ is most important for neurotransmission in unmyelinated neurones and is a target for antinociceptive drugs [240]. PKC activation rapidly increases calcium currents in sensory neurones [241], an effect which may have a complex origin as subtypes 2.2 and 2.3 are enhanced by PKC activation while 1.1-1.4 are inhibited [242-244]. Calcium channels can be rapidly inhibited by $\mathrm{G}_{\mathrm{i}}$-protein coupled receptors activated by opioids [245], which is mediated via the $G$-protein $\beta / \gamma$ subunits [246]. An second mechanism which may play an important role in nociception is the activation of $\mathrm{Ca}_{\mathrm{V}} 3.1$ (T-type) calcium channels by reducing agents and endogenous L-cysteine [247].

\section{HCN Channels}

Hyperpolarisation-activated cyclic nucleotide gated channels generate $I_{h}$ pacemaker currents in the heart [248]. The hyperpolarisation-evoked current can be enhanced by cAMP and, to a lesser extent, by cGMP by direct binding to a C-terminal site, which causes a shift in channel activation to more positive membrane potentials [249]. Voltage-clamp studies in DRG neurones showed that large neurones expressed a fast, cAMP-insensitive $\mathrm{I}_{\mathrm{h}}$ in large neurones, and that this current was abolished by genetic deletion of $\mathrm{HCN} 1$, while in small neurones a slower, cAMP-sensitive current, consistent with expression of HCN2, was seen [250]. In small neurones the enhanced generation of action potentials caused by exposure to $\mathrm{PGE}_{2}$ was found to be entirely attributable to the cAMP-sensitivity of $\mathrm{I}_{\mathrm{h}}$, and other factors such as modulation of $\mathrm{Na}$ currents (see above) played at most a marginal role [250]. For HCN2, the voltagedependent activation is shifted by intracellular $\mathrm{pH}$ which might increase the role in tissue acidosis [251]. In addition HCN channels can be sensitised by Src and PIP $_{2}$ (see table 1) though the importance of this for nociceptors function is currently unknown.

\section{CONCLUSION}

Sensitisation is a property unique to nociceptors - all other sensory receptors adapt to an intense or prolonged stimulus. The function of sensitisation is to enhance the urgency of a painful stimulus so that action is taken to preserve the integrity of the organism. As such it has been subjected to many millennia of evolution and has become a complex and multifaceted process. In this review we have outlined our current understanding of this vital process at the level of the peripheral sensory neurones. Sensitisation at the level of central pathways also has an important role to play but is beyond the scope of this review. We have identified three main stages of sensitisation: the production of inflammatory mediators which initiate sensitisation; the activation of intracellular signalling pathways; and the ion channel targets which ultimately modulate the electrical response of the nociceptor. Our knowledge in these areas will guide the development of future analgesics to control the pain associated with tissue damage and inflammation.

$$
\begin{aligned}
& \text { ABBREVIATIONS } \\
& \text { 5-HT }=\text {-hydroxytryptamine, serotonin } \\
& \text { AKAP }=\text { A-kinase anchoring protein } \\
& \text { ASIC }=\text { Acid-sensing ion channels } \\
& \text { cAMP }=\text { Cyclic adenosine monophosphate } \\
& \text { cGMP }=\text { Cyclic guanosine monophosphate } \\
& \text { CGRP }=\text { Calcitonin gene-related peptide } \\
& \text { DRG }=\text { Dorsal root ganglion } \\
& \text { EET } \\
& \text { ERK }
\end{aligned}
$$

\section{REFERENCES}

[1] McMahon S, Koltzenburg M. Wall and Melzack's Textbook of Pain. 5th ed. Churchill Livingstone, 2005.

[2] Millan MJ. The induction of pain: an integrative review. Prog Neurobiol 1999; 57(1): 1-164.

[3] Handwerker HO, Kilo S, Reeh PW. Unresponsive afferent nerve fibres in the sural nerve of the rat. J Physiol 1991; 435: 229-242. 
[4] Meyer RA, Davis KD, Cohen RH, Treede RD, Campbell JN. Mechanically insensitive afferents (MIAs) in cutaneous nerves of monkey. Brain Res 1991; 561(2): 252-261.

[5] Cervero F, Laird JM. Visceral pain. Lancet 1999; 353(9170): 21452148.

[6] Robinson DR, Gebhart GF. Inside information: the unique features of visceral sensation. Mol Interv 2008; 8(5): 242-253.

[7] Perry MJ, Lawson SN. Differences in expression of oligosaccharides, neuropeptides, carbonic anhydrase and neurofilament in rat primary afferent neurones retrogradely labelled via skin, muscle or visceral nerves. Neuroscience 1998; 85(1): 293310 .

[8] Moalem G, Tracey DJ. Immune and inflammatory mechanisms in neuropathic pain. Brain Res Rev 2006; 51(2): 240-264.

[9] Ryan GB, Majno G. Acute inflammation. A review. Am J Pathol 1977; 86(1): 183-276.

[10] Ratnoff OD. Mediators of inflammation. J Allergy Clin Immunol 1976; 58(3): 438-446.

[11] Kessler W, Kirchhoff C, Reeh PW, Handwerker HO. Excitation of cutaneous afferent nerve endings in vitro by a combination of inflammatory mediators and conditioning effect of substance P. Exp Brain Res 1992; 91(3): 467-476.

[12] Manning DC, Raja SN, Meyer RA, Campbell JN. Pain and hyperalgesia after intradermal injection of bradykinin in humans. Clin Pharmacol Ther 1991; 50(6): 721-729.

[13] Kaplan AP, Joseph K, Silverberg M. Pathways for bradykinin formation and inflammatory disease. J Allergy Clin Immunol 2002; 109(2): 195-209.

[14] Schmaier AH. Assembly, activation, and physiologic influence of the plasma kallikrein/kinin system. Int Immunopharmacol 2008; 8(2): 161-165.

[15] Rupniak NM, Boyce S, Webb JK, et al. Effects of the bradykinin $\mathrm{B}_{1}$ receptor antagonist des-Arg9[Leu8]bradykinin and genetic disruption of the $\mathrm{B}_{2}$ receptor on nociception in rats and mice. Pain 1997; 71(1): 89-97.

[16] McEachern AE, Shelton ER, Bhakta S, et al. Expression cloning of a rat $\mathrm{B}_{2}$ bradykinin receptor. Proc Natl Acad Sci U S A 1991; 88(17): 7724-7728.

[17] Biyashev D, Tan F, Chen Z, et al. Kallikrein activates bradykinin $\mathrm{B}_{2}$ receptors in absence of kininogen. Am J Physiol Heart Circ Physiol 2006; 290(3): H1244-H1250.

[18] Fox A, Wotherspoon G, McNair K, et al. Regulation and function of spinal and peripheral neuronal $\mathrm{B}_{1}$ bradykinin receptors in inflammatory mechanical hyperalgesia. Pain 2003; 104(3): 683691.

[19] Vellani V, Zachrisson O, McNaughton PA. Functional bradykinin $\mathrm{B}_{1}$ receptors are expressed in nociceptive neurones and are upregulated by the neurotrophin GDNF. J Physiol 2004; 560(Pt 2): 391-401.

[20] Wang H, Ehnert C, Brenner GJ, Woolf CJ. Bradykinin and peripheral sensitisation. Biol Chem 2006; 387(1): 11-14.

[21] Geppetti P, Maggi CA, Perretti F, Frilli S, Manzini S. Simultaneous release by bradykinin of substance $\mathrm{P}$ - and calcitonin gene-related peptide immunoreactivities from capsaicin-sensitive structures in guinea-pig heart. Br J Pharmacol 1988; 94(2): 288-290.

[22] Cunha TM, Verri WA, Jr., Fukada SY, et al. TNF-alpha and IL1 beta mediate inflammatory hypernociception in mice triggered by $\mathrm{B}_{1}$ but not $\mathrm{B}_{2}$ kinin receptor. Eur J Pharmacol 2007; 573(1-3): 221 229.

[23] Turner DJ, Gupta K, Yang XX, Martin JG. Bradykinin-induced airway constriction in guinea-pigs: role of leukotriene $\mathrm{D}(4)$. Pulm Pharmacol Ther 2000; 13(4): 181-188.

[24] Ferreira SH. Prostaglandins, aspirin-like drugs and analgesia. Nat New Biol 1972; 240(102): 200-203.

[25] Ferreira SH, Nakamura M, Abreu Castro MS. The hyperalgesic effects of prostacyclin and prostaglandin E2. Prostaglandins 1978; 16(1): 31-37.

[26] Taiwo YO, Levine JD. Characterization of the arachidonic acid metabolites mediating bradykinin and noradrenaline hyperalgesia. Brain Res 1988; 458(2): 402-406.

[27] Bley KR, Hunter JC, Eglen RM, Smith JA. The role of IP prostanoid receptors in inflammatory pain. Trends Pharmacol Sci 1998; 19(4): 141-147.

[28] Coleman RA, Smith WL, Narumiya S. International Union of Pharmacology classification of prostanoid receptors: properties, distribution, and structure of the receptors and their subtypes. Pharmacol Rev 1994; 46(2): 205-229.

[29] Ferreira SH, Nakamura M. I - Prostaglandin hyperalgesia, a cAMP/Ca2 + dependent process. Prostaglandins 1979; 18(2): 179 190.

[30] Averbeck B, Peisler M, Izydorczyk I, Reeh PW. Inflammatory mediators do not stimulate CGRP release if prostaglandin synthesis is blocked by $\mathrm{S}(+)$-flurbiprofen in isolated rat skin. Inflamm Res 2003; 52(12): 519-523.

[31] Meves H. The action of prostaglandins on ion channels. Curr Neuropharmacol 2006; 4(1): 41-57.

[32] Hucho TB, Dina OA, Levine JD. Epac mediates a cAMP-to-PKC signaling in inflammatory pain: an isolectin B4(+) neuron-specific mechanism. J Neurosci 2005; 25(26): 6119-6126.

[33] Wang C, Gu Y, Li GW, Huang LY. A critical role of the cAMP sensor Epac in switching protein kinase signalling in prostaglandin E2-induced potentiation of $\mathrm{P} 2 \mathrm{X} 3$ receptor currents in inflamed rats. J Physiol 2007; 584(Pt 1): 191-203.

[34] Vetter I, Kapitzke D, Hermanussen S, Monteith GR, Cabot PJ. The effects of $\mathrm{pH}$ on beta-endorphin and morphine inhibition of calcium transients in dorsal root ganglion neurones. J Pain 2006; 7(7): 488-499.

[35] Levine JD, Lau W, Kwiat G, Goetzl EJ. Leukotriene B4 produces hyperalgesia that is dependent on polymorphonuclear leukocytes. Science 1984; 225(4663): 743-745.

[36] Yoo S, Han S, Park YS, Lee JH, Oh U, Hwang SW. Lipoxygenase inhibitors suppressed carrageenan-induced Fos-expression and inflammatory pain responses in the rat. Mol Cells 2009; 27(4): 417422 .

[37] Inceoglu B, Schmelzer KR, Morisseau C, Jinks SL, Hammock BD. Soluble epoxide hydrolase inhibition reveals novel biological functions of epoxyeicosatrienoic acids (EETs). Prostaglandins Other Lipid Mediat 2007; 82(1-4): 42-49.

[38] Drummond PD. The effect of cutaneous mast cell degranulation on sensitivity to heat. Inflamm Res 2004; 53(7): 309-315.

[39] Kulka M, Sheen CH, Tancowny BP, Grammer LC, Schleimer RP. Neuropeptides activate human mast cell degranulation and chemokine production. Immunology 2008; 123(3): 398-410.

[40] Koppert W, Martus P, Reeh PW. Interactions of histamine and bradykinin on polymodal C-fibres in isolated rat skin. Eur J Pain 2001; 5(1): 97-106.

[41] Millan MJ. Serotonin (5-HT) and pain: A reappraisal of its role in the light of receptor multiplicity. Seminars in Neuroscience 1995; 7(6): 409-419.

[42] Sommer C. Serotonin in pain and analgesia: actions in the periphery. Mol Neurobiol 2004; 30(2): 117-125.

[43] Abbott FV, Hong Y, Blier P. Activation of $5-\mathrm{HT}_{2 \mathrm{~A}}$ receptors potentiates pain produced by inflammatory mediators. Neuropharmacology 1996; 35(1): 99-110.

[44] Okamoto $\mathrm{K}$, Imbe $\mathrm{H}$, Morikawa $\mathrm{Y}$, et al. 5- $\mathrm{HT}_{2 \mathrm{~A}}$ receptor subtype in the peripheral branch of sensory fibers is involved in the potentiation of inflammatory pain in rats. Pain 2002; 99(1-2): 133143.

[45] Goadsby PJ. Serotonin receptors and the acute attack of migraine. Clin Neurosci 1998; 5(1): 18-23.

[46] Gold MS, Reichling DB, Shuster MJ, Levine JD. Hyperalgesic agents increase a tetrodotoxin-resistant $\mathrm{Na}+$ current in nociceptors Proc Natl Acad Sci U S A 1996; 93(3): 1108-1112.

[47] Soga F, Katoh N, Inoue T, Kishimoto S. Serotonin activates human monocytes and prevents apoptosis. J Invest Dermatol 2007; 127(8): 1947-1955.

[48] Ito T, Ikeda U, Shimpo M, Yamamoto K, Shimada K. Serotonin increases interleukin-6 synthesis in human vascular smooth muscle cells. Circulation 2000; 102(20): 2522-2527.

[49] Simmen HP, Battaglia H, Giovanoli P, Blaser J. Analysis of pH, $\mathrm{pO} 2$ and $\mathrm{pCO} 2$ in drainage fluid allows for rapid detection of infectious complications during the follow-up period after abdominal surgery. Infection 1994; 22(6): 386-389.

[50] Woo YC, Park SS, Subieta AR, Brennan TJ. Changes in tissue pH and temperature after incision indicate acidosis may contribute to postoperative pain. Anesthesiology 2004; 101(2): 468-475.

[51] Steen KH, Reeh PW. Sustained graded pain and hyperalgesia from harmless experimental tissue acidosis in human skin. Neurosci Lett 1993; 154(1-2): 113-116. 
[52] Sauer SK, Weidner C, Carr RW, et al. Can receptor potentials be detected with threshold tracking in rat cutaneous nociceptive terminals? J Neurophysiol 2005; 94(1): 219-225.

[53] Benitah J, Balser JR, Marban E, Tomaselli GF. Proton inhibition of sodium channels: mechanism of gating shifts and reduced conductance. J Membr Biol 1997; 155(2): 121-131.

[54] Holzer P. Sensory neurones responses to mucosal noxae in the upper gut: relevance to mucosal integrity and gastrointestinal pain. Neurogastroenterol Motil 2002; 14(5): 459-475.

[55] Kress M, Reeh PW, Vyklicky L. An interaction of inflammatory mediators and protons in small diameter dorsal root ganglion neurones of the rat. Neurosci Lett 1997; 224(1): 37-40.

[56] Steen KH, Steen AE, Kreysel HW, Reeh PW. Inflammatory mediators potentiate pain induced by experimental tissue acidosis. Pain 1996; 66(2-3): 163-170.

[57] King BF, Wildman SS, Ziganshina LE, Pintor J, Burnstock G. Effects of extracellular $\mathrm{pH}$ on agonism and antagonism at a recombinant P2X2 receptor. Br J Pharmacol 1997; 121(7): 14451453.

[58] Crandall M, Kwash J, Yu W, White G. Activation of protein kinase $\mathrm{C}$ sensitises human VR1 to capsaicin and to moderate decreases in $\mathrm{pH}$ at physiological temperatures in Xenopus oocytes. Pain 2002; 98(1-2): 109-117.

[59] Cook SP, McCleskey EW. Cell damage excites nociceptors through release of cytosolic ATP. Pain 2002; 95(1-2): 41-47.

[60] Kobayashi K, Fukuoka T, Yamanaka H, et al. Neurones and glial cells differentially express $\mathrm{P} 2 \mathrm{Y}$ receptor mRNAs in the rat dorsal root ganglion and spinal cord. J Comp Neurol 2006; 498(4): 443454.

[61] Gerevich Z, Muller C, Illes P. Metabotropic $\mathrm{P}_{2} \mathrm{Y}_{1}$ receptors inhibit $\mathrm{P} 2 \mathrm{X} 3$ receptor-channels in rat dorsal root ganglion neurones. Eur $\mathrm{J}$ Pharmacol 2005; 521(1-3): 34-38.

[62] Tominaga M, Wada M, Masu M. Potentiation of capsaicin receptor activity by metabotropic ATP receptors as a possible mechanism for ATP-evoked pain and hyperalgesia. Proc Natl Acad Sci U S A 2001; 98(12): 6951-6956.

[63] Moriyama T, Iida T, Kobayashi K, et al. Possible involvement of P2Y2 metabotropic receptors in ATP-induced transient receptor potential vanilloid receptor 1-mediated thermal hypersensitivity. J Neurosci 2003; 23(14): 6058-6062.

[64] Yang L, Cranson D, Trinkaus-Randall V. Cellular injury induces activation of MAPK via P2Y receptors. J Cell Biochem 2004; 91(5): 938-950.

[65] Molliver DC, Cook SP, Carlsten JA, Wright DE, McCleskey EW. ATP and UTP excite sensory neurones and induce CREB phosphorylation through the metabotropic receptor, P2Y2. Eur J Neurosci 2002; 16(10): 1850-1860.

[66] Jarvis MF, Mikusa J, Chu KL, et al. Comparison of the ability of adenosine kinase inhibitors and adenosine receptor agonists to attenuate thermal hyperalgesia and reduce motor performance in rats. Pharmacol Biochem Behav 2002; 73(3): 573-581.

[67] McMahon SB. NGF as a mediator of inflammatory pain. Philos Trans R Soc Lond B Biol Sci 1996; 351(1338): 431-440.

[68] Ciobanu C, Reid G, Babes A. Acute and chronic effects of neurotrophic factors BDNF and GDNF on responses mediated by thermo-sensitive TRP channels in cultured rat dorsal root ganglion neurones. Brain Res 2009; 1284: 54-67.

[69] Pezet S, McMahon SB. Neurotrophins: mediators and modulators of pain. Annu Rev Neurosci 2006; 29: 507-538.

[70] Freund-Michel V, Frossard N. The nerve growth factor and its receptors in airway inflammatory diseases. Pharmacol Ther 2008; 117(1): 52-76.

[71] Shu X, Mendell LM. Nerve growth factor acutely sensitises the response of adult rat sensory neurones to capsaicin. Neurosci Lett 1999; 274(3): 159-162.

[72] Bonnington JK, McNaughton PA. Signalling pathways involved in the sensitisation of mouse nociceptive neurones by nerve growth factor. J Physiol 2003; 551(Pt 2): 433-446.

[73] Zhang X, Huang J, McNaughton PA. NGF rapidly increases membrane expression of TRPV1 heat-gated ion channels. EMBO J 2005; 24(24): 4211-4223.

[74] Zhu W, Oxford GS. Phosphoinositide-3-kinase and mitogen activated protein kinase signaling pathways mediate acute NGF sensitisation of TRPV1. Mol Cell Neurosci 2007; 34(4): 689-700.
[75] Stempelj M, Ferjan I. Signaling pathway in nerve growth factor induced histamine release from rat mast cells. Inflamm Res 2005; 54(8): 344-349.

[76] Linker R, Gold R, Luhder F. Function of neurotrophic factors beyond the nervous system: inflammation and autoimmune demyelination. Crit Rev Immunol 2009; 29(1): 43-68.

[77] Mamet J, Lazdunski M, Voilley N. How nerve growth factor drives physiological and inflammatory expressions of acid-sensing ion channel 3 in sensory neurones. J Biol Chem 2003; 278(49): 4890748913.

[78] Ji RR, Samad TA, Jin SX, Schmoll R, Woolf CJ. p38 MAPK activation by NGF in primary sensory neurones after inflammation increases TRPV1 levels and maintains heat hyperalgesia. Neurone 2002; 36(1): 57-68.

[79] Xu P, Hall AK. Activin acts with nerve growth factor to regulate calcitonin gene-related peptide mRNA in sensory neurones. Neuroscience 2007; 150(3): 665-674.

[80] Lee YJ, Zachrisson O, Tonge DA, McNaughton PA. Upregulation of bradykinin $\mathrm{B}_{2}$ receptor expression by neurotrophic factors and nerve injury in mouse sensory neurones. Mol Cell Neurosci 2002; 19(2): 186-200.

[81] Vizzard MA, Erdman SL, de Groat WC. Increased expression of neuronal nitric oxide synthase in dorsal root ganglion neurones after systemic capsaicin administration. Neuroscience 1995; 67(1): $1-5$.

[82] Zhang X, Verge V, Wiesenfeld-Hallin Z, et al. Nitric oxide synthase-like immunoreactivity in lumbar dorsal root ganglia and spinal cord of rat and monkey and effect of peripheral axotomy. J Comp Neurol 1993; 335(4): 563-575.

[83] Eberhardt M, Neeb L, Vogel E, et al. Glyceroltrinitrate facilitates stimulated CGRP release but not gene expression of CGRP or its receptor components in rat trigeminal ganglia. Neuropeptides 2009; (in press).

[84] Lawand NB, Willis WD, Westlund KN. Blockade of joint inflammation and secondary hyperalgesia by L-NAME, a nitric oxide synthase inhibitor. Neuroreport 1997; 8(4): 895-899.

[85] Burgess GM, Mullaney I, McNeill M, Coote PR, Minhas A, Wood $\mathrm{JN}$. Activation of guanylate cyclase by bradykinin in rat sensory neurones is mediated by calcium influx: possible role of the increase in cyclic GMP. J Neurochem 1989; 53(4): 1212-1218.

[86] Lin Q, Peng YB, Wu J, Willis WD. Involvement of cGMP in nociceptive processing by and sensitisation of spinothalamic neurones in primates. J Neurosci 1997; 17(9): 3293-3302.

[87] Holthusen H, Ding Z. Nitric oxide is not involved in vascular nociception of noxious physical stimuli in humans. Neurosci Lett 1997; 227(2): 111-114.

[88] Kress M, Rodl J, Reeh PW. Stable analogues of cyclic AMP but not cyclic GMP sensitise unmyelinated primary afferents in rat skin to heat stimulation but not to inflammatory mediators, in vitro. Neuroscience 1996; 74(2): 609-617.

[89] Lipton SA, Gu Z, Nakamura T. Inflammatory mediators leading to protein misfolding and uncompetitive/fast off-rate drug therapy for neurodegenerative disorders. Int Rev Neurobiol 2007; 82: 1-27.

[90] Toriyabe M, Omote K, Kawamata T, Namiki A. Contribution of interaction between nitric oxide and cyclooxygenases to the production of prostaglandins in carrageenan-induced inflammation. Anesthesiology 2004; 101(4): 983-990.

[91] Rittner HL, Brack A, Stein C. Pain and the immune system. Br J Anaesth 2008; 101(1): 40-44.

[92] Cunha TM, Verri WA, Jr., Silva JS, Poole S, Cunha FQ, Ferreira $\mathrm{SH}$. A cascade of cytokines mediates mechanical inflammatory hypernociception in mice. Proc Natl Acad Sci U S A 2005; 102(5): $1755-1760$.

[93] Li Y, Ji A, Weihe E, Schafer MK. Cell-specific expression and lipopolysaccharide-induced regulation of tumor necrosis factor alpha (TNFalpha) and TNF receptors in rat dorsal root ganglion. J Neurosci 2004; 24(43): 9623-9631.

[94] Woolf CJ, Allchorne A, Safieh-Garabedian B, Poole S. Cytokines, nerve growth factor and inflammatory hyperalgesia: the contribution of tumour necrosis factor alpha. Br J Pharmacol 1997; 121(3): 417-424.

[95] Rittner HL, Machelska H, Stein C. Leukocytes in the regulation of pain and analgesia. J Leukoc Biol 2005; 78(6): 1215-1222.

[96] Ren K, Torres R. Role of interleukin-1beta during pain and inflammation. Brain Res Rev 2009; 60(1): 57-64. 
[97] Jin X, Gereau RW. Acute p38-mediated modulation of tetrodotoxin-resistant sodium channels in mouse sensory neurones by tumor necrosis factor-alpha. J Neurosci 2006; 26(1): 246-255.

[98] Obreja O, Biasio W, Andratsch M, et al. Fast modulation of heatactivated ionic current by proinflammatory interleukin 6 in rat sensory neurones. Brain 2005; 128(Pt 7): 1634-1641.

[99] Oh SB, Tran PB, Gillard SE, Hurley RW, Hammond DL, Miller RJ. Chemokines and glycoprotein 120 produce pain hypersensitivity by directly exciting primary nociceptive neurones. J Neurosci 2001; 21(14): 5027-5035.

[100] Zhang N, Inan S, Cowan A, et al. A proinflammatory chemokine, CCL3, sensitises the heat- and capsaicin-gated ion channel TRPV1. Proc Natl Acad Sci U S A 2005; 102(12): 4536-4541.

[101] Qin X, Wan Y, Wang X. CCL2 and CXCL1 trigger calcitonin gene-related peptide release by exciting primary nociceptive neurones. J Neurosci Res 2005; 82(1): 51-62.

[102] White FA, Bhangoo SK, Miller RJ. Chemokines: integrators of pain and inflammation. Nat Rev Drug Discov 2005; 4(10): 834844.

[103] Lin DC, Bullock CM, Ehlert FJ, Chen JL, Tian H, Zhou QY. Identification and molecular characterization of two closely related $\mathrm{G}$ protein-coupled receptors activated by prokineticins/endocrine gland vascular endothelial growth factor. J Biol Chem 2002; 277(22): 19276-19280.

[104] Negri L, Lattanzi R, Giannini E, et al. Impaired nociception and inflammatory pain sensation in mice lacking the prokineticin receptor PKR1: focus on interaction between PKR1 and the capsaicin receptor TRPV1 in pain behavior. J Neurosci 2006; 26(25): 6716-6727.

[105] Negri L, Lattanzi R, Giannini E, et al. Nociceptive sensitisation by the secretory protein Bv8. Br J Pharmacol 2002; 137(8): 11471154.

[106] Vellani V, Colucci M, Lattanzi R, et al. Sensitisation of transient receptor potential vanilloid 1 by the prokineticin receptor agonist Bv8. J Neurosci 2006; 26(19): 5109-5116.

[107] Amadesi S, Cottrell GS, Divino L, et al. Protease-activated receptor 2 sensitises TRPV1 by protein kinase Cepsilon- and Adependent mechanisms in rats and mice. J Physiol 2006; 575(Pt 2): 555-571.

[108] Barford D. Molecular mechanisms of the protein serine/threonine phosphatases. Trends Biochem Sci 1996; 21(11): 407-412.

[109] Mohapatra DP, Nau C. Regulation of $\mathrm{Ca} 2+$-dependent desensitisation in the vanilloid receptor TRPV1 by calcineurin and cAMP-dependent protein kinase. J Biol Chem 2005; 280(14): 13424-13432.

[110] Docherty RJ, Yeats JC, Bevan S, Boddeke HW. Inhibition of calcineurin inhibits the desensitisation of capsaicin-evoked currents in cultured dorsal root ganglion neurones from adult rats. Pflugers Arch 1996; 431(6): 828-837.

[111] Chung HJ, Qian X, Ehlers M, Jan YN, Jan LY. Neuronal activity regulates phosphorylation-dependent surface delivery of $\mathrm{G}$ proteinactivated inwardly rectifying potassium channels. Proc Natl Acad Sci U S A 2009; 106(2): 629-634.

[112] Morenilla-Palao C, Planells-Cases R, Garcia-Sanz N, FerrerMontiel A. Regulated exocytosis contributes to protein kinase C potentiation of vanilloid receptor activity. J Biol Chem 2004; 279(24): 25665-25672.

[113] Taiwo YO, Bjerknes LK, Goetzl EJ, Levine JD. Mediation of primary afferent peripheral hyperalgesia by the cAMP second messenger system. Neuroscience 1989; 32(3): 577-580.

[114] Premkumar LS, Raisinghani M, Pingle SC, Long C, Pimentel F. Downregulation of transient receptor potential melastatin 8 by protein kinase C-mediated dephosphorylation. J Neurosci 2005; 25(49): 11322-11329.

[115] Rathee PK, Distler C, Obreja O, et al. PKA/AKAP/VR-1 module: A common link of Gs-mediated signaling to thermal hyperalgesia. $\mathrm{J}$ Neurosci 2002; 22(11): 4740-4745.

[116] Burgess GM, Mullaney I, McNeill M, Dunn PM, Rang HP. Second messengers involved in the mechanism of action of bradykinin in sensory neurones in culture. J Neurosci 1989; 9(9): 3314-3325.

[117] Velazquez KT, Mohammad H, Sweitzer SM. Protein kinase C in pain: involvement of multiple isoforms. Pharmacol Res 2007; 55(6): 578-589.

[118] Cesare P, McNaughton P. A novel heat-activated current in nociceptive neurones and its sensitisation by bradykinin. Proc Natl Acad Sci U S A 1996; 93(26): 15435-15439.
[119] Khasar SG, Lin YH, Martin A, et al. A novel nociceptor signaling pathway revealed in protein kinase $\mathrm{C}$ epsilon mutant mice. Neuron 1999; 24(1): 253-260.

[120] Olah Z, Karai L, Iadarola MJ. Protein kinase C(alpha) is required for vanilloid receptor 1 activation. Evidence for multiple signaling pathways. J Biol Chem 2002; 277(38): 35752-35759.

[121] Kim H, Sasaki T, Maeda K, Koya D, Kashiwagi A, Yasuda H. Protein kinase Cbeta selective inhibitor LY333531 attenuates diabetic hyperalgesia through ameliorating cGMP level of dorsal root ganglion neurones. Diabetes 2003; 52(8): 2102-2109.

[122] Kessler F, Habelt C, Averbeck B, Reeh PW, Kress M. Heatinduced release of CGRP from isolated rat skin and effects of bradykinin and the protein kinase C activator PMA. Pain 1999; 83(2): 289-295.

[123] Premkumar LS, Ahern GP. Induction of vanilloid receptor channel activity by protein kinase C. Nature 2000; 408(6815): 985-990.

[124] Dina OA, Barletta J, Chen X, et al. Key role for the epsilon isoform of protein kinase $\mathrm{C}$ in painful alcoholic neuropathy in the rat. $\mathrm{J}$ Neurosci 2000; 20(22): 8614-8619.

[125] Joseph EK, Levine JD. Sexual dimorphism in the contribution of protein kinase $\mathrm{C}$ isoforms to nociception in the streptozotocin diabetic rat. Neuroscience 2003; 120(4): 907-913.

[126] Ahlgren SC, Levine JD. Protein kinase C inhibitors decrease hyperalgesia and C-fiber hyperexcitability in the streptozotocindiabetic rat. J Neurophysiol 1994; 72(2): 684-692.

[127] McConnachie G, Langeberg LK, Scott JD. AKAP signaling complexes: getting to the heart of the matter. Trends Mol Med 2006; 12(7): 317-323.

[128] Zhang X, Li L, McNaughton PA. Proinflammatory mediators modulate the heat-activated ion channel TRPV1 via the scaffolding protein AKAP79/150. Neurone 2008; 59(3): 450-461

[129] Fan HC, Zhang X, McNaughton PA. Activation of the TRPV4 ion channel is enhanced by phosphorylation. J Biol Chem 2009; 284(41): 27884-27891.

[130] Ji RR, Gereau RW, Malcangio M, Strichartz GR. MAP kinase and pain. Brain Res Rev 2009; 60(1): 135-148.

[131] Ji RR, Suter MR. p38 MAPK, microglial signaling, and neuropathic pain. Mol Pain 2007; 3: 33.

[132] Averill S, Delcroix JD, Michael GJ, Tomlinson DR, Fernyhough P, Priestley JV. Nerve growth factor modulates the activation status and fast axonal transport of ERK $1 / 2$ in adult nociceptive neurones. Mol Cell Neurosci 2001; 18(2): 183-196.

[133] Dai Y, Iwata K, Fukuoka T, et al. Phosphorylation of extracellular signal-regulated kinase in primary afferent neurones by noxious stimuli and its involvement in peripheral sensitisation. J Neurosci 2002; 22(17): 7737-7745.

[134] Obata K, Yamanaka H, Dai Y, et al. Differential activation of extracellular signal-regulated protein kinase in primary afferent neurones regulates brain-derived neurotrophic factor expression after peripheral inflammation and nerve injury. J Neurosci 2003; 23(10): 4117-4126.

[135] Delcroix JD, Valletta JS, Wu C, Hunt SJ, Kowal AS, Mobley WC. NGF signaling in sensory neurones: evidence that early endosomes carry NGF retrograde signals. Neurone 2003; 39(1): 69-84.

[136] Mizushima T, Obata K, Yamanaka H, et al. Activation of p38 MAPK in primary afferent neurones by noxious stimulation and its involvement in the development of thermal hyperalgesia. Pain 2005; 113(1-2): 51-60.

[137] Kim SY, Bae JC, Kim JY, et al. Activation of p38 MAP kinase in the rat dorsal root ganglia and spinal cord following peripheral inflammation and nerve injury. Neuroreport 2002; 13(18): 24832486

[138] Doya H, Ohtori S, Fujitani M, et al. c-Jun N-terminal kinase activation in dorsal root ganglion contributes to pain hypersensitivity. Biochem Biophys Res Commun 2005; 335(1): 132-138.

[139] Pollock J, McFarlane SM, Connell MC, et al. TNF-alpha receptors simultaneously activate $\mathrm{Ca} 2+$ mobilisation and stress kinases in cultured sensory neurones. Neuropharmacology 2002; 42(1): 93106.

[140] Mulderry PK, Dobson SP. Regulation of VIP and other neuropeptides by c-Jun in sensory neurones: implications for the neuropeptide response to axotomy. Eur J Neurosci 1996; 8(12): 2479-2491. 
[141] Hilgemann DW, Feng S, Nasuhoglu C. The complex and intriguing lives of PIP2 with ion channels and transporters. Sci STKE 2001; 2001(111): RE19.

[142] Hardie RC. TRP channels and lipids: from Drosophila to mammalian physiology. J Physiol 2007; 578(Pt 1): 9-24.

[143] Daniels RL, Takashima Y, McKemy DD. Activity of the neuronal cold sensor TRPM8 is regulated by phospholipase $\mathrm{C}$ via the phospholipid phosphoinositol 4,5-bisphosphate. J Biol Chem 2009; 284(3): 1570-1582.

[144] McCleskey EW, Gold MS. Ion channels of nociception. Annu Rev Physiol 1999; 61: 835-856.

[145] Patapoutian A, Tate S, Woolf CJ. Transient receptor potential channels: targeting pain at the source. Nat Rev Drug Discov 2009; 8(1): 55-68.

[146] Montell C, Rubin GM. Molecular characterization of the Drosophila trp locus: a putative integral membrane protein required for phototransduction. Neurone 1989; 2(4): 1313-1323.

[147] Ramsey IS, Delling M, Clapham DE. An introduction to TRP channels. Annu Rev Physiol 2006; 68: 619-647.

[148] Kobayashi K, Fukuoka T, Obata K, et al. Distinct expression of TRPM8, TRPA1, and TRPV1 mRNAs in rat primary afferent neurones with adelta/c-fibers and colocalization with trk receptors. J Comp Neurol 2005; 493(4): 596-606.

[149] Caterina MJ, Schumacher MA, Tominaga M, Rosen TA, Levine JD, Julius D. The capsaicin receptor: a heat-activated ion channel in the pain pathway. Nature 1997; 389(6653): 816-824.

[150] Willis WD, Jr. The role of TRPV1 receptors in pain evoked by noxious thermal and chemical stimuli. Exp Brain Res 2009; 196(1): 5-11.

[151] Caterina MJ, Leffler A, Malmberg AB, et al. Impaired nociception and pain sensation in mice lacking the capsaicin receptor. Science 2000; 288(5464): 306-313.

[152] Davis JB, Gray J, Gunthorpe MJ, et al. Vanilloid receptor-1 is essential for inflammatory thermal hyperalgesia. Nature 2000; 405(6783): 183-187.

[153] Jin X, Morsy N, Winston J, Pasricha PJ, Garrett K, Akbarali HI. Modulation of TRPV1 by nonreceptor tyrosine kinase, c-Src kinase. Am J Physiol Cell Physiol 2004; 287(2): C558-C563.

[154] Cesare P, Dekker LV, Sardini A, Parker PJ, McNaughton PA. Specific involvement of PKC-epsilon in sensitisation of the neuronal response to painful heat. Neuron 1999; 23(3): 617-624.

[155] Bhave G, Zhu W, Wang H, Brasier DJ, Oxford GS, Gereau RW. cAMP-dependent protein kinase regulates desensitisation of the capsaicin receptor (VR1) by direct phosphorylation. Neurone 2002; 35(4): 721-731.

[156] Numazaki M, Tominaga T, Toyooka H, Tominaga M. Direct phosphorylation of capsaicin receptor VR1 by protein kinase Cepsilon and identification of two target serine residues. J Biol Chem 2002; 277(16): 13375-13378.

[157] Chuang HH, Prescott ED, Kong H, et al. Bradykinin and nerve growth factor release the capsaicin receptor from Ptdins $(4,5) \mathrm{P} 2$ mediated inhibition. Nature 2001; 411(6840): 957-962.

[158] Stein AT, Ufret-Vincenty CA, Hua L, Santana LF, Gordon SE. Phosphoinositide 3-kinase binds to TRPV1 and mediates NGFstimulated TRPV1 trafficking to the plasma membrane. J Gen Physiol 2006; 128(5): 509-522.

[159] Van Buren JJ, Bhat S, Rotello R, Pauza ME, Premkumar LS. Sensitisation and translocation of TRPV1 by insulin and IGF-I. Mol Pain 2005; 1: 17.

[160] Amaya F, Oh-hashi K, Naruse Y, et al. Local inflammation increases vanilloid receptor 1 expression within distinct subgroups of DRG neurones. Brain Res 2003; 963(1-2): 190-196.

[161] Nilius B. TRP channels in disease. Biochim Biophys Acta 2007; 1772(8): 805-812.

[162] Spitzer MJ, Reeh PW, Sauer SK. Mechanisms of potassium- and capsaicin-induced axonal calcitonin gene-related peptide release: involvement of L- and T-type calcium channels and TRPV1 but not sodium channels. Neuroscience 2008; 151(3): 836-842.

[163] Story GM, Peier AM, Reeve AJ, et al. ANKTM1, a TRP-like channel expressed in nociceptive neurones, is activated by cold temperatures. Cell 2003; 112(6): 819-829.

[164] Jordt SE, Bautista DM, Chuang HH, et al. Mustard oils and cannabinoids excite sensory nerve fibres through the TRP channel ANKTM1. Nature 2004; 427(6971): 260-265.

[165] Macpherson LJ, Dubin AE, Evans MJ, Marr F, Schultz PG, Cravatt $\mathrm{BF}$ et al. Noxious compounds activate TRPA1 ion channels through covalent modification of cysteines. Nature 2007; 445(7127): 541-545.

[166] Hinman A, Chuang HH, Bautista DM, Julius D. TRP channel activation by reversible covalent modification. Proc Natl Acad Sci U S A 2006; 103(51): 19564-19568.

[167] Kwan KY, Allchorne AJ, Vollrath MA, et al. TRPA1 contributes to cold, mechanical, and chemical nociception but is not essential for hair-cell transduction. Neurone 2006; 50(2): 277-289.

[168] Zurborg S, Yurgionas B, Jira JA, Caspani O, Heppenstall PA. Direct activation of the ion channel TRPA1 by Ca2+. Nat Neurosci 2007; 10(3): 277-279.

[169] Wang YY, Chang RB, Waters HN, McKemy DD, Liman ER. The nociceptor ion channel TRPA1 is potentiated and inactivated by permeating calcium ions. J Biol Chem 2008; 283(47): 3269132703 .

[170] Wang S, Dai Y, Fukuoka T, et al. Phospholipase C and protein kinase A mediate bradykinin sensitisation of TRPA1: a molecular mechanism of inflammatory pain. Brain 2008; 131(Pt 5): 12411251.

[171] Dai Y, Wang S, Tominaga M, et al. Sensitisation of TRPA1 by PAR2 contributes to the sensation of inflammatory pain. J Clin Invest 2007; 117(7): 1979-1987.

[172] Karashima Y, Talavera K, Everaerts W, et al. TRPA1 acts as a cold sensor in vitro and in vivo. Proc Natl Acad Sci U S A 2009; 106(4): 1273-1278.

[173] Forster AB, Reeh PW, Messlinger K, Fischer MJ. High concentrations of morphine sensitise and activate mouse dorsal root ganglia via TRPV1 and TRPA1 receptors. Mol Pain 2009; 5: 17.

[174] Bautista DM, Sigal YM, Milstein AD, et al. Pungent agents from Szechuan peppers excite sensory neurones by inhibiting two-pore potassium channels. Nat Neurosci 2008; 11(7): 772-779.

[175] McKemy DD, Neuhausser WM, Julius D. Identification of a cold receptor reveals a general role for TRP channels in thermosensation. Nature 2002; 416(6876): 52-58.

[176] Peier AM, Moqrich A, Hergarden AC, et al. A TRP channel that senses cold stimuli and menthol. Cell 2002; 108(5): 705-715.

[177] Linte RM, Ciobanu C, Reid G, Babes A. Desensitisation of coldand menthol-sensitive rat dorsal root ganglion neurones by inflammatory mediators. Exp Brain Res 2007; 178(1): 89-98.

[178] Rohacs T, Lopes CM, Michailidis I, Logothetis DE. PI(4,5)P2 regulates the activation and desensitisation of TRPM8 channels through the TRP domain. Nat Neurosci 2005; 8(5): 626-634.

[179] Colburn RW, Lubin ML, Stone DJ, Jr., et al. Attenuated cold sensitivity in TRPM8 null mice. Neurone 2007; 54(3): 379-386.

[180] Dhaka A, Murray AN, Mathur J, Earley TJ, Petrus MJ, Patapoutian A. TRPM8 is required for cold sensation in mice. Neurone 2007; 54(3): 371-378.

[181] Chung MK, Caterina MJ. TRP channel knockout mice lose their cool. Neurone 2007; 54(3): 345-347.

[182] Mukerji G, Yiangou Y, Corcoran SL, et al. Cool and menthol receptor TRPM8 in human urinary bladder disorders and clinical correlations. BMC Urol 2006; 6: 6 .

[183] Leffler A, Linte RM, Nau C, Reeh P, Babes A. A high-threshold heat-activated channel in cultured rat dorsal root ganglion neurones resembles TRPV2 and is blocked by gadolinium. Eur J Neurosci 2007; 26(1): 12-22.

[184] Moqrich A, Hwang SW, Earley TJ, et al. Impaired thermosensation in mice lacking TRPV3, a heat and camphor sensor in the skin. Science 2005; 307(5714): 1468-1472.

[185] Chung MK, Lee H, Mizuno A, Suzuki M, Caterina MJ. 2aminoethoxydiphenyl borate activates and sensitises the heat-gated ion channel TRPV3. J Neurosci 2004; 24(22): 5177-5182.

[186] Zimmermann K, Leffler A, Fischer MM, Messlinger K, Nau C, Reeh PW. The TRPV1/2/3 activator 2-aminoethoxydiphenyl borate sensitises native nociceptive neurones to heat in wildtype but not TRPV1 deficient mice. Neuroscience 2005; 135(4): 1277-1284.

[187] Watanabe H, Davis JB, Smart D, et al. Activation of TRPV4 channels (hVRL-2/mTRP12) by phorbol derivatives. J Biol Chem 2002; 277(16): 13569-13577.

[188] Suzuki M, Mizuno A, Kodaira K, Imai M. Impaired pressure sensation in mice lacking TRPV4. J Biol Chem 2003; 278(25): 22664-22668.

[189] Yoshida T, Inoue R, Morii T, et al. Nitric oxide activates TRP channels by cysteine S-nitrosylation. Nat Chem Biol 2006; 2(11): 596-607. 
[190] Novakova-Tousova K, Vyklicky L, Susankova K, et al. Functional changes in the vanilloid receptor subtype 1 channel during and after acute desensitisation. Neuroscience 2007; 149(1): 144-154

[191] Kress M, Karasek J, Ferrer-Montiel AV, Scherbakov N, Haberberger RV. TRPC channels and diacylglycerol dependent calcium signaling in rat sensory neurones. Histochem Cell Biol 2008; 130(4): 655-667.

[192] Schaefer M. Homo- and heteromeric assembly of TRP channel subunits. Pflugers Arch 2005; 451(1): 35-42.

[193] Strubing C, Krapivinsky G, Krapivinsky L, Clapham DE. TRPC1 and TRPC5 form a novel cation channel in mammalian brain. Neurone 2001; 29(3): 645-655.

[194] Staaf S, Oerther S, Lucas G, Mattsson JP, Ernfors P. Differential regulation of TRP channels in a rat model of neuropathic pain. Pain 2009; 144(1-2): 187-199.

[195] Waldmann R, Lazdunski M. H(+)-gated cation channels: neuronal acid sensors in the NaC/DEG family of ion channels. Curr Opin Neurobiol 1998; 8(3): 418-424.

[196] Cadiou H, Studer M, Jones NG, et al. Modulation of acid-sensing ion channel activity by nitric oxide. J Neurosci 2007; 27(48): 13251-13260.

[197] Deval E, Salinas M, Baron A, Lingueglia E, Lazdunski M. ASIC2b-dependent regulation of ASIC3, an essential acid-sensing ion channel subunit in sensory neurones via the partner protein PICK-1. J Biol Chem 2004; 279(19): 19531-19539.

[198] Donnelly-Roberts D, McGaraughty S, Shieh CC, Honore P, Jarvis MF. Painful purinergic receptors. J Pharmacol Exp Ther 2008; 324(2): 409-415

[199] Bleehen T, Keele CA. Observations on the algogenic actions of adenosine compounds on the human blister base preparation. Pain 1977; 3(4): 367-377.

[200] Khakh BS, North RA. P2X receptors as cell-surface ATP sensors in health and disease. Nature 2006; 442(7102): 527-532.

[201] Hamilton SG, Warburton J, Bhattacharjee A, Ward J, McMahon SB. ATP in human skin elicits a dose-related pain response which is potentiated under conditions of hyperalgesia. Brain 2000; 123 ( Pt 6): 1238-1246.

[202] Franklin C, Braam U, Eisele T, Schmalzing G, Hausmann R. Lack of evidence for direct phosphorylation of recombinantly expressed $\mathrm{P} 2 \mathrm{X}(2)$ and $\mathrm{P} 2 \mathrm{X}$ (3) receptors by protein kinase C. Purinergic Signal 2007; 3(4): 377-388.

[203] D'Arco M, Giniatullin R, Leone V, et al. The C-terminal Src inhibitory kinase (Csk)-mediated tyrosine phosphorylation is a novel molecular mechanism to limit $\mathrm{P} 2 \mathrm{X} 3$ receptor function in mouse sensory neurones. J Biol Chem 2009; 284(32): 2139321401.

[204] Solle M, Labasi J, Perregaux DG, et al. Altered cytokine production in mice lacking $\mathrm{P} 2 \mathrm{X}(7)$ receptors. J Biol Chem 2001; 276(1): 125-132.

[205] Chessell IP, Hatcher JP, Bountra C, et al. Disruption of the P2X7 purinoceptor gene abolishes chronic inflammatory and neuropathic pain. Pain 2005; 114(3): 386-396.

[206] Wang GK, Russell C, Wang SY. State-dependent block of voltagegated $\mathrm{Na}+$ channels by amitriptyline via the local anesthetic receptor and its implication for neuropathic pain. Pain 2004; 110 (12): 166-174

[207] Fukuoka T, Kobayashi K, Yamanaka H, Obata K, Dai Y, Noguchi $\mathrm{K}$. Comparative study of the distribution of the alpha-subunits of voltage-gated sodium channels in normal and axotomized rat dorsal root ganglion neurones. J Comp Neurol 2008; 510(2): 188-206.

[208] Black JA, Liu S, Tanaka M, Cummins TR, Waxman SG. Changes in the expression of tetrodotoxin-sensitive sodium channels within dorsal root ganglia neurones in inflammatory pain. Pain 2004; 108(3): 237-247.

[209] Gould HJ, III, England JD, Soignier RD, et al. Ibuprofen blocks changes in $\mathrm{Na} \mathrm{v} 1.7$ and 1.8 sodium channels associated with complete Freund's adjuvant-induced inflammation in rat. J Pain 2004; 5(5): 270-280.

[210] Fang X, McMullan S, Lawson SN, Djouhri L. Electrophysiological differences between nociceptive and non-nociceptive dorsal root ganglion neurones in the rat in vivo. J Physiol 2005; 565(Pt 3): 927943.

[211] Akopian AN, Souslova V, England S, et al. The tetrodotoxinresistant sodium channel SNS has a specialized function in pain pathways. Nat Neurosci 1999; 2(6): 541-548.
[212] Cummins TR, Dib-Hajj SD, Black JA, Akopian AN, Wood JN Waxman SG. A novel persistent tetrodotoxin-resistant sodium current in SNS-null and wild-type small primary sensory neurones. J Neurosci 1999; 19(24): RC43.

[213] Catterall WA, Goldin AL, Waxman SG. International Union of Pharmacology. XLVII. Nomenclature and structure-function relationships of voltage-gated sodium channels. Pharmacol Rev 2005; 57(4): 397-409.

[214] Gold MS. Tetrodotoxin-resistant $\mathrm{Na}+$ currents and inflammatory hyperalgesia. Proc Natl Acad Sci U S A 1999; 96(14): 7645-7649.

[215] Cantrell AR, Catterall WA. Neuromodulation of Na+ channels: an unexpected form of cellular plasticity. Nat Rev Neurosci 2001; 2(6): 397-407.

[216] England S, Bevan S, Docherty RJ. PGE2 modulates the tetrodotoxin-resistant sodium current in neonatal rat dorsal root ganglion neurones via the cyclic AMP-protein kinase A cascade. J Physiol 1996; 495 ( Pt 2): 429-440.

[217] Smith RD, Goldin AL. Functional analysis of the rat I sodium channel in xenopus oocytes. J Neurosci 1998; 18(3): 811-820.

[218] Dascal N, Lotan I. Activation of protein kinase C alters voltage dependence of a Na+ channel. Neurone 1991; 6(1): 165-175.

[219] Klugbauer N, Lacinova L, Flockerzi V, Hofmann F. Structure and functional expression of a new member of the tetrodotoxinsensitive voltage-activated sodium channel family from human neuroendocrine cells. EMBO J 1995; 14(6): 1084-1090.

[220] Cummins TR, Howe JR, Waxman SG. Slow closed-state inactivation: a novel mechanism underlying ramp currents in cells expressing the hNE/PN1 sodium channel. J Neurosci 1998; 18(23): 9607-9619.

[221] Vijayaragavan K, Boutjdir M, Chahine M. Modulation of Nav1.7 and Nav1.8 peripheral nerve sodium channels by protein kinase A and protein kinase C. J Neurophysiol 2004; 91(4): 1556-1569.

[222] Nassar MA, Stirling LC, Forlani G, et al. Nociceptor-specific gene deletion reveals a major role for Nav1.7 (PN1) in acute and inflammatory pain. Proc Natl Acad Sci U S A 2004; 101(34): 12706-12711.

[223] Akopian AN, Souslova V, Sivilotti L, Wood JN. Structure and distribution of a broadly expressed atypical sodium channel. FEBS Lett 1997; 400(2): 183-187.

[224] Rush AM, Cummins TR, Waxman SG. Multiple sodium channels and their roles in electrogenesis within dorsal root ganglion neurones. J Physiol 2007; 579(Pt 1): 1-14

[225] Fitzgerald EM, Okuse K, Wood JN, Dolphin AC, Moss SJ. cAMPdependent phosphorylation of the tetrodotoxin-resistant voltagedependent sodium channel SNS. J Physiol 1999; 516 ( Pt 2): 433446.

[226] Matthews EA, Wood JN, Dickenson AH. Na(v) 1.8-null mice show stimulus-dependent deficits in spinal neuronal activity. Mol Pain 2006; $2: 5$.

[227] Rush AM, Waxman SG. PGE2 increases the tetrodotoxin-resistant Nav1.9 sodium current in mouse DRG neurones via G-proteins. Brain Res 2004; 1023(2): 264-271.

[228] Tate S, Benn S, Hick C, et al. Two sodium channels contribute to the TTX-R sodium current in primary sensory neurones. Nat Neurosci 1998; 1(8): 653-655.

[229] Priest BT, Murphy BA, Lindia JA, et al. Contribution of the tetrodotoxin-resistant voltage-gated sodium channel NaV1.9 to sensory transmission and nociceptive behavior. Proc Natl Acad Sci U S A 2005; 102(26): 9382-9387.

[230] Baker MD. Protein kinase $C$ mediates up-regulation of tetrodotoxin-resistant, persistent $\mathrm{Na}+$ current in rat and mouse sensory neurones. J Physiol 2005; 567(Pt 3): 851-867.

[231] Hille B. Ion channels of exciable membranes. 3rd ed. Sinauer Associates, 2001.

[232] Yi BA, Minor DL, Jr., Lin YF, Jan YN, Jan LY. Controlling potassium channel activities: Interplay between the membrane and intracellular factors. Proc Natl Acad Sci U S A 2001; 98(20): 11016-11023.

[233] Nicol GD, Vasko MR, Evans AR. Prostaglandins suppress an outward potassium current in embryonic rat sensory neurones. J Neurophysiol 1997; 77(1): 167-176.

[234] Lev S, Moreno H, Martinez R, et al. Protein tyrosine kinase PYK2 involved in $\mathrm{Ca}(2+)$-induced regulation of ion channel and MAP kinase functions. Nature 1995; 376(6543): 737-745. 
[235] Sharma N, D'Arcangelo G, Kleinlaus A, Halegoua S, Trimmer JS. Nerve growth factor regulates the abundance and distribution of $\mathrm{K}+$ channels in PC12 cells. J Cell Biol 1993; 123(6 Pt 2): 1835-1843.

[236] Louise Faber ES. Functions and Modulation of Neuronal SK Channels. Cell Biochem Biophys 2009; 55(3): 127-139.

[237] Kaczmarek LK, Blumenthal EM. Properties and regulation of the minK potassium channel protein. Physiol Rev 1997; 77(3): 627641.

[238] Dunlap K, Fischbach GD. Neurotransmitters decrease the calcium conductance activated by depolarization of embryonic chick sensory neurones. J Physiol 1981; 317: 519-535.

[239] Bean BP. Neurotransmitter inhibition of neuronal calcium currents by changes in channel voltage dependence. Nature 1989; 340(6229): 153-156.

[240] Schroeder JE, Fischbach PS, Zheng D, McCleskey EW. Activation of mu opioid receptors inhibits transient high- and low-threshold Ca2+ currents, but spares a sustained current. Neurone 1991; 6(1): 13-20.

[241] Swartz KJ. Modulation of $\mathrm{Ca} 2+$ channels by protein kinase $\mathrm{C}$ in rat central and peripheral neurones: disruption of $\mathrm{G}$ protein-mediated inhibition. Neurone 1993; 11(2): 305-320.

[242] Kamatchi GL, Tiwari SN, Chan CK, et al. Distinct regulation of expressed calcium channels 2.3 in Xenopus oocytes by direct or indirect activation of protein kinase C. Brain Res 2003; 968(2): 227-237.

[243] Ito $Y$, Murai $Y$, Ishibashi H, Onoue H, Akaike N. The prostaglandin $\mathrm{E}$ series modulates high-voltage-activated calcium channels probably through the EP3 receptor in rat paratracheal ganglia. Neuropharmacology 2000; 39(2): 181-190.

[244] Borgland SL, Connor M, Ryan RM, Ball HJ, Christie MJ. Prostaglandin E(2) inhibits calcium current in two sub-populations of acutely isolated mouse trigeminal sensory neurones. J Physiol 2002; 539(Pt 2): 433-444.

[245] Zamponi GW, Snutch TP. Modulation of voltage-dependent calcium channels by G proteins. Curr Opin Neurobiol 1998; 8(3): 351-356.

[246] Herlitze S, Garcia DE, Mackie K, Hille B, Scheuer T, Catterall WA. Modulation of $\mathrm{Ca} 2+$ channels by G-protein beta gamma subunits. Nature 1996; 380(6571): 258-262.

[247] Nelson MT, Joksovic PM, Perez-Reyes E, Todorovic SM. The endogenous redox agent L-cysteine induces T-type $\mathrm{Ca} 2+$ channeldependent sensitisation of a novel subpopulation of rat peripheral nociceptors. J Neurosci 2005; 25(38): 8766-8775.

[248] Ludwig A, Zong X, Jeglitsch M, Hofmann F, Biel M. A family of hyperpolarization-activated mammalian cation channels. Nature 1998; 393(6685): 587-591.

[249] DiFrancesco D, Tortora P. Direct activation of cardiac pacemaker channels by intracellular cyclic AMP. Nature 1991; 351(6322): 145-147.

[250] Momin A, Cadiou H, Mason A, McNaughton PA. Role of the hyperpolarization-activated current Ih in somatosensory neurones. J Physiol 2008; 586(Pt 24): 5911-5929.

[251] Zong X, Stieber J, Ludwig A, Hofmann F, Biel M. A single histidine residue determines the $\mathrm{pH}$ sensitivity of the pacemaker channel HCN2. J Biol Chem 2001; 276(9): 6313-6319.

[252] Bhave $\mathrm{G}, \mathrm{Hu} \mathrm{HJ}$, Glauner $\mathrm{KS}$, et al. Protein kinase $\mathrm{C}$ phosphorylation sensitises but does not activate the capsaicin receptor transient receptor potential vanilloid 1 (TRPV1). Proc Natl Acad Sci U S A 2003; 100(21): 12480-12485.

[253] Kim AY, Tang Z, Liu Q, et al. Pirt, a phosphoinositide-binding protein, functions as a regulatory subunit of TRPV1. Cell 2008; 133(3): 475-485.

[254] Lukacs V, Thyagarajan B, Varnai P, Balla A, Balla T, Rohacs T. Dual regulation of TRPV1 by phosphoinositides. J Neurosci 2007; 27(26): 7070-7080.

[255] Klein RM, Ufret-Vincenty CA, Hua L, Gordon SE. Determinants of molecular specificity in phosphoinositide regulation. Phosphatidylinositol (4,5)-bisphosphate $(\mathrm{PI}(4,5) \mathrm{P} 2)$ is the endogenous lipid regulating TRPV1. J Biol Chem 2008; 283(38): 26208-26216.

[256] Leffler A, Fischer MJ, Rehner D, et al. The vanilloid receptor TRPV1 is activated and sensitised by local anesthetics in rodent sensory neurones. J Clin Invest 2008; 118(2): 763-776.

[257] Prescott ED, Julius D. A modular PIP2 binding site as a determinant of capsaicin receptor sensitivity. Science 2003; 300(5623): 1284-1288.
[258] Nicholas RS, Winter J, Wren P, Bergmann R, Woolf CJ. Peripheral inflammation increases the capsaicin sensitivity of dorsal root ganglion neurones in a nerve growth factor-dependent manner. Neuroscience 1999; 91(4): 1425-1433.

[259] Cao DS, Yu SQ, Premkumar LS. Modulation of transient receptor potential Vanilloid 4-mediated membrane currents and synaptic transmission by protein kinase C. Mol Pain 2009; $5: 5$.

[260] Alessandri-Haber N, Dina OA, Joseph EK, Reichling DB, Levine JD. Interaction of transient receptor potential vanilloid 4, integrin, and SRC tyrosine kinase in mechanical hyperalgesia. J Neurosci 2008; 28(5): 1046-1057.

[261] Wegierski T, Lewandrowski U, Muller B, Sickmann A, Walz G. Tyrosine phosphorylation modulates the activity of TRPV4 in response to defined stimuli. J Biol Chem 2009; 284(5): 2923-2933.

[262] Sipe WE, Brierley SM, Martin CM, et al. Transient receptor potential vanilloid 4 mediates protease activated receptor 2 -induced sensitisation of colonic afferent nerves and visceral hyperalgesia. Am J Physiol Gastrointest Liver Physiol 2008; 294(5): G1288G1298.

[263] Kochukov MY, McNearney TA, Yin H, et al. Tumor necrosis factor- alpha (TNF-alpha) enhances functional thermal and chemical responses of TRP cation channels in human synoviocytes. Mol Pain 2009; 5(1): 49.

[264] De Petrocellis L, Starowicz K, Moriello AS, Vivese M, Orlando P, Di Marzo V. Regulation of transient receptor potential channels of melastatin type 8 (TRPM8): effect of cAMP, cannabinoid CB(1) receptors and endovanilloids. Exp Cell Res 2007; 313(9): 19111920.

[265] Liu B, Qin F. Functional control of cold- and menthol-sensitive TRPM8 ion channels by phosphatidylinositol 4,5-bisphosphate. J Neurosci 2005; 25(7): 1674-1681.

[266] Obata K, Katsura H, Mizushima T, et al. TRPA1 induced in sensory neurones contributes to cold hyperalgesia after inflammation and nerve injury. J Clin Invest 2005; 115(9): 23932401.

[267] Karashima Y, Prenen J, Meseguer V, Owsianik G, Voets T, Nilius B. Modulation of the transient receptor potential channel TRPA1 by phosphatidylinositol 4,5-biphosphate manipulators. Pflugers Arch 2008; 457(1): 77-89.

[268] Kim D, Cavanaugh EJ, Simkin D. Inhibition of transient receptor potential A1 channel by phosphatidylinositol-4,5-bisphosphate. Am J Physiol Cell Physiol 2008; 295(1): C92-C99.

[269] Dunham JP, Kelly S, Donaldson LF. Inflammation reduces mechanical thresholds in a population of transient receptor potential channel A1-expressing nociceptors in the rat. Eur $\mathrm{J}$ Neurosci 2008; 27(12): 3151-3160.

[270] Baron A, Deval E, Salinas M, Lingueglia E, Voilley N, Lazdunski M. Protein kinase $\mathrm{C}$ stimulates the acid-sensing ion channel ASIC2a via the PDZ domain-containing protein PICK1. J Biol Chem 2002; 277(52): 50463-50468.

[271] Voilley N, de Weille J, Mamet J, Lazdunski M. Nonsteroid antiinflammatory drugs inhibit both the activity and the inflammationinduced expression of acid-sensing ion channels in nociceptors. J Neurosci 2001; 21(20): 8026-8033.

[272] Duan B, Wu LJ, Yu YQ, et al. Upregulation of acid-sensing ion channel ASIC1a in spinal dorsal horn neurones contributes to inflammatory pain hypersensitivity. J Neurosci 2007; 27(41): 11139-11148.

[273] Brown DA, Yule DI. Protein kinase C regulation of P2X3 receptors is unlikely to involve direct receptor phosphorylation. Biochim Biophys Acta 2007; 1773(2): 166-175.

[274] Bie BH, Zhang YH, Zhao ZQ. Inhibition of P2X receptor-mediated inward current by protein kinase $\mathrm{C}$ in small-diameter dorsal root ganglion neurones of adult rats. Neurosci Bull 2009; 25(4): 179186.

[275] Bernier LP, Ase AR, Tong X, et al. Direct modulation of P2X1 receptor-channels by the lipid phosphatidylinositol 4,5bisphosphate. Mol Pharmacol 2008; 74(3): 785-792.

[276] Ambalavanar R, Moritani M, Dessem D. Trigeminal P2X3 receptor expression differs from dorsal root ganglion and is modulated by deep tissue inflammation. Pain 2005; 117(3): 280-291.

[277] Xu GY, Huang LY. Peripheral inflammation sensitises P2X receptor-mediated responses in rat dorsal root ganglion neurones. J Neurosci 2002; 22(1): 93-102.

[278] Chatelier A, Dahllund L, Eriksson A, Krupp J, Chahine M. Biophysical properties of human Na v1.7 splice variants and their 
regulation by protein kinase A. J Neurophysiol 2008; 99(5): 22412250.

[279] Keh SM, Facer P, Simpson KD, Sandhu G, Saleh HA, Anand P. Increased nerve fiber expression of sensory sodium channels Nav1.7, Nav1.8, And Nav1.9 in rhinitis. Laryngoscope 2008; 118(4): 573-579.

[280] Matsumoto S, Yoshida S, Ikeda M, et al. Effect of 8-bromo-cAMP on the tetrodotoxin-resistant sodium (Nav 1.8) current in smalldiameter nodose ganglion neurones. Neuropharmacology 2007; 52(3): 904-924.

[281] Cang CL, Zhang H, Zhang YQ, Zhao ZQ. PKCepsilon-dependent potentiation of TTX-resistant Nav1.8 current by neurokinin-1 receptor activation in rat dorsal root ganglion neurones. Mol Pain 2009; 5: 33 .

[282] Copel C, Osorio N, Crest M, Gola M, Delmas P, Clerc N. Activation of neurokinin 3 receptor increases $\mathrm{Na}(\mathrm{v}) 1.9$ current in enteric neurones. J Physiol 2009; 587(Pt 7): 1461-1479.

[283] Huang XY, Morielli AD, Peralta EG. Molecular basis of cardiac potassium channel stimulation by protein kinase A. Proc Natl Acad Sci U S A 1994; 91(2): 624-628.

[284] Wang WH, Giebisch G. Dual modulation of renal ATP-sensitive $\mathrm{K}+$ channel by protein kinases A and C. Proc Natl Acad Sci U S A 1991; 88(21): 9722-9725.

[285] Fakler B, Brandle U, Glowatzki E, Zenner HP, Ruppersberg JP. Kir2.1 inward rectifier $\mathrm{K}+$ channels are regulated independently by protein kinases and ATP hydrolysis. Neurone 1994; 13(6): 14131420.

[286] Besana A, Robinson RB, Feinmark SJ. Lipids and two-pore domain $\mathrm{K}+$ channels in excitable cells. Prostaglandins Other Lipid Mediat 2005; 77(1-4): 103-110.

[287] Covarrubias M, Wei A, Salkoff L, Vyas TB. Elimination of rapid potassium channel inactivation by phosphorylation of the inactivation gate. Neurone 1994; 13(6): 1403-1412.

[288] Rojas A, Su J, Yang L, et al. Modulation of the heteromeric Kir4.1Kir5.1 channel by multiple neurotransmitters via Galphaq-coupled receptors. J Cell Physiol 2008; 214(1): 84-95.
[289] Holmes TC, Fadool DA, Levitan IB. Tyrosine phosphorylation of the Kv1.3 potassium channel. J Neurosci 1996; 16(5): 1581-1590.

[290] Zhou W, Arrabit C, Choe S, Slesinger PA. Mechanism underlying bupivacaine inhibition of $\mathrm{G}$ protein-gated inwardly rectifying $\mathrm{K}+$ channels. Proc Natl Acad Sci U S A 2001; 98(11): 6482-6487.

[291] Stea A, Soong TW, Snutch TP. Determinants of PKC-dependent modulation of a family of neuronal calcium channels. Neurone 1995; 15(4): 929-940.

[292] Connor M, Henderson G. Bradykinin inhibition of N- and L-type calcium channel currents in NG108-15 cells. Neuropharmacology 1997; 36(1): 115-124.

[293] Roberts-Crowley ML, Mitra-Ganguli T, Liu L, Rittenhouse AR. Regulation of voltage-gated $\mathrm{Ca} 2+$ channels by lipids. Cell Calcium 2009; 45(6): 589-601.

[294] Roullet JB, Spaetgens RL, Burlingame T, Feng ZP, Zamponi GW. Modulation of neuronal voltage-gated calcium channels by farnesol. J Biol Chem 1999; 274(36): 25439-25446.

[295] Fogle KJ, Lyashchenko AK, Turbendian HK, Tibbs GR. HCN pacemaker channel activation is controlled by acidic lipids downstream of diacylglycerol kinase and phospholipase A2. J Neurosci 2007; 27(11): 2802-2814.

[296] Zong X, Eckert C, Yuan H, et al. A novel mechanism of modulation of hyperpolarization-activated cyclic nucleotide-gated channels by Src kinase. J Biol Chem 2005; 280(40): 34224-34232.

[297] Li CH, Zhang Q, Teng B, Mustafa SJ, Huang JY, Yu HG. Src tyrosine kinase alters gating of hyperpolarization-activated $\mathrm{HCN} 4$ pacemaker channel through Tyr531. Am J Physiol Cell Physiol 2008; 294(1): C355-C362.

[298] Pian P, Bucchi A, Robinson RB, Siegelbaum SA. Regulation of gating and rundown of $\mathrm{HCN}$ hyperpolarization-activated channels by exogenous and endogenous PIP2. J Gen Physiol 2006; 128(5): 593-604.

[299] Cho HJ, Staikopoulos V, Furness JB, Jennings EA. Inflammationinduced increase in hyperpolarization-activated, cyclic nucleotidegated channel protein in trigeminal ganglion neurones and the effect of buprenorphine. Neuroscience 2009; 162(2): 453-461.

Received: September 24, 2009

Revised: October 02, 2009

Accepted: August 18, 2010

(C) Fischer et al.; Licensee Bentham Open.

This is an open access article licensed under the terms of the Creative Commons Attribution Non-Commercial License (http://creativecommons.org/licenses/by-nc/3.0/) which permits unrestricted, non-commercial use, distribution and reproduction in any medium, provided the work is properly cited. 